\title{
Political Regimes and Deaths in the Early Stages of the COVID-19 Pandemic
}

\author{
Gabriel Cepaluni \\ UNESP-Franca
}

\author{
Michael T. Dorsch* \\ Central European University
}

\author{
Réka Branyiczki \\ Central European University
}

April 27, 2020

\begin{abstract}
This paper provides a quantitative examination of the link between political institutions and deaths during the first 100 days of the COVID-19 pandemic. We demonstrate that countries with more democratic political institutions experienced deaths on a larger per capita scale and sooner than less democratic countries. The result is robust to the inclusion of many relevant controls, a battery of estimation techniques, and to estimation with instruments for the institutional measures that we consider. Additionally, we examine the extent to which COVID-19 deaths were impacted heterogeneously by policy responses across types of political institutions. Policy responses in democracies were less effective in reducing deaths in the early stages of the crisis. The results imply that democratic political institutions may have a disadvantage in responding quickly to pandemics.
\end{abstract}

Keywords: COVID-19, pandemics, political institutions, democracy

Word count: 8330 (including bibliography). 11188 (including title page, bibliography and appendix)

\footnotetext{
*Corresponding author. Central European University, School of Public Policy, Nádor u. 9, 1051 Budapest, Hungary; dorschm@ceu.edu. We thank Fernando Bizarro, Caitlin Brown, László Bruszt, Cristina Corduneanu-Huci, Raphael Cunha, Amanda Driscoll, Mihály Fazekas, Ivan Filipe Fernandes, Danilo Freire, Giampaolo Garzarelli, Julius Horvath, Evelyne Hubscher, Miklós Koren, Paul Maarek, Alexandru Moise, Anand Murugesan, Kata Orosz, and Michael Touchton for comments that improved the analysis presented here.
} 


\section{Introduction}

The early stages of the COVID-19 pandemic has seen remarkable state interventions in social and business life on a scale not seen since World War II. Since that disruptive time, many countries have shifted towards democratic governance, experienced unprecedented rates of economic growth and globalization, and greatly improved the health of their populations. Indeed, there is a large literature on the positive impact that democracy has on public health (Bellinger 2019; Besley and Kudamatsu 2006; Fujiwara 2015; Justesen 2012; Patterson and Veenstra 2016; Welander, Lyttkens and Nilsson 2015; Wigley and Akkoyunlu-Wigley 2017). ${ }^{1}$ However, securing public health during a novel pandemic is quite different. How political regimes have dealt with the COVID-19 public health crisis in its early stages is the question that we address in this paper.

On December 31, 2019, China alerted the World Health Organization (WHO) to an outbreak of pneumonia of an unknown cause in the city of Wuhan in Hubei province. The epidemic quickly spread, with cases of COVID-19 confirmed throughout China and elsewhere in the world. The Chinese government's forceful response had drawn initial praise from global health officials (Kavanagh, 2020). Other autocratic countries in the region were also fast to act. On February 18, 2020 and March 10, 2020, the WHO praised Singapore's initial efforts to contain COVID-19 infections through aggressive tracing and quarantining of close contacts, as well as comprehensive testing of every case of influenza-like illness and pneumonia. While many international medical experts praised Singapore's efforts to control the outbreak, others argued that this could well continue the erosion of civil liberties in the city-state (Singer and Sang-Hun, 2020). At the same time, the United States and other European democracies (e.g. Italy, France and Spain) have struggled to fight COVID-19 while balancing defense of their civil liberties and economies. Figure 1 plots the evolution of COVID-19 deaths in some selected countries.

Recent research has shown that political factors have influenced policy responses and the public's adherence to COVID-19 regulations. Within the context of the United States, Adolph et al. (2020) show

\footnotetext{
${ }^{1}$ The result is, however, disputed by some scholars, notably, Truex 2017 in a global sensitivity analysis. Furthermore, democracy may not improve the health of the poor (Ross 2006; van der Windt and Vandoros 2017).
} 
Figure 1: Logarithmic chart of COVID-19 Deaths per capita - Selected countries

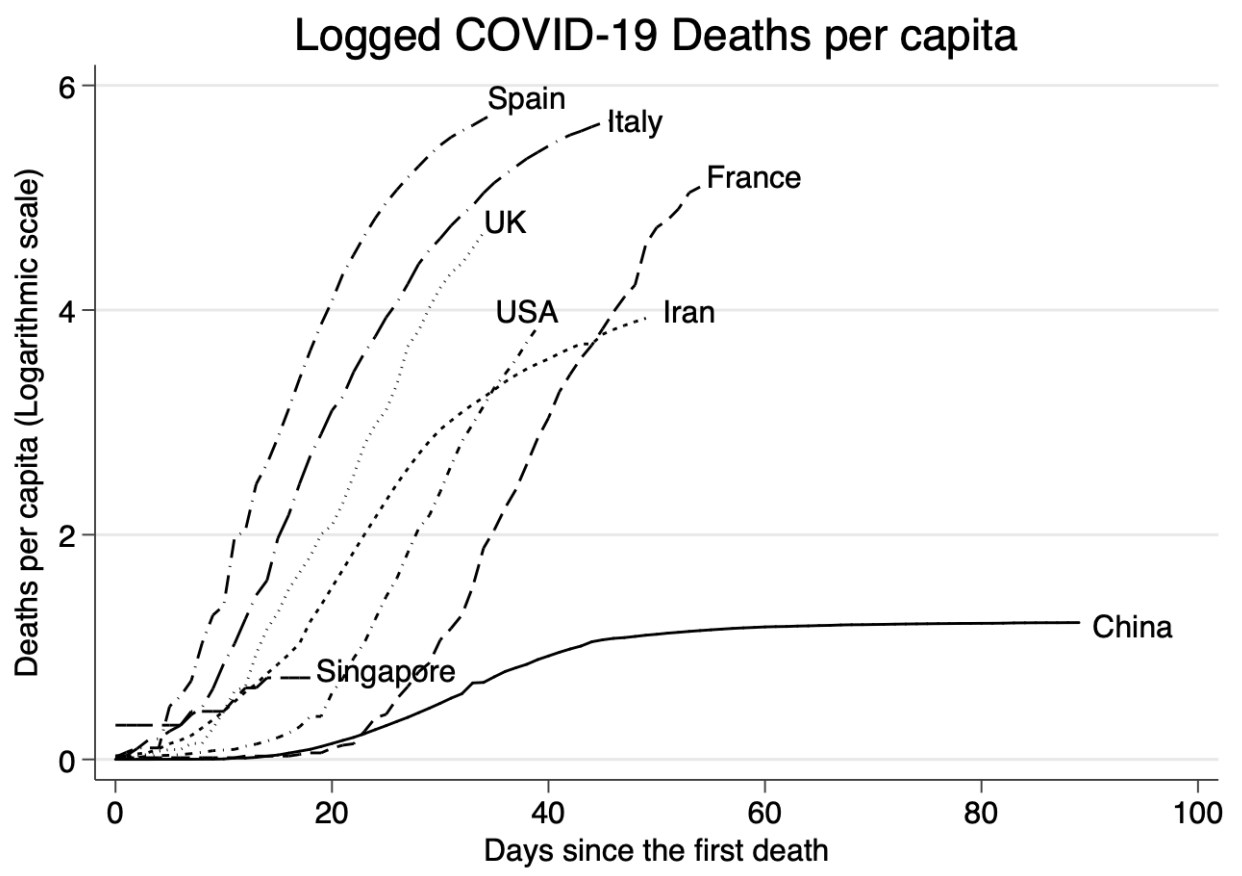

that states with Republican governors and more Trump supporters were slower to adopt social distancing policies. Tracking data from smartphones, research has also shown similar partisan divides among individuals: areas of the United States with more Republicans practice less social distancing (Allcott et al., 2020; Barrios and Hochberg, 2020). In a cross-country context, Cronert (2020) show that more democratic governments were faster to shut down schools, though governments with higher state capacity were slower to do so. Our analysis, by contrast, focuses on the number of per capita deaths related to COVID-19 in the early stages of the pandemic. ${ }^{2}$ Using a variety of empirical techniques, we show that more democratic countries experienced more per capita deaths, were sooner to experience deaths, and have enacted less stringent and less effective policy responses.

The results are sobering for advocates of liberal democracy. In general, social scientists tend to agree that democratic governance yields better economic, health, and social outcomes through more informed, rigorous and accountable policy-making processes (e.g. Acemoglu et al. 2019; Acemoglu and Robinson 2012; Besley 2006; Bollyky et al. 2019; Dorsch and Maarek 2019; Przeworski and Limongi

\footnotetext{
${ }^{2}$ Appendix Figure A.1 shows the geographic distribution of deaths and policy response stringency.
} 
1993; Wittman 1989). However, the same features of democracy that are thought to yield better public policies also work to constrain the speed and incisiveness of democratic decision-making (Malesky and London, 2014; Weeks, 2008). Therein lies the trade-off in democracy that the COVID-19 crisis exposes: policy responses that impinge on personal liberties and privacy that could have contained the spread of the virus were not pursued in the early stages of the crisis.

The debate on the trade-off between protecting lives and preserving freedom is centuries old. Thomas Hobbes wrote that an absolute sovereign - the Leviathan - is the best solution to protect the lives of its citizens and that civil liberties are of secondary value (Hobbes, 1970). Carl Schmitt argues that a sovereign maintain the capacity to initiate a "state of exception" in order to speed up the slow processes of democratic politics and its bureaucracy, and that every government capable of decisive action must include a dictatorial element within its constitution (Schmitt, 2005). Alternatively, the liberal tradition places greater emphasis on protecting civil liberties. John Stuart Mill states that it is illegitimate to infringe civil liberties, and that power can be exercised rightfully over a citizen only to prevent harm to others (Mill, 1887). John Dewey also praises democracy because it provides freedom for the individual to participate in an informed way in the political sphere (Dewey, 1923). In his seminal account of democracy, Robert Dahl warns against the appeal of an elite of experts or "wise men" by arguing that a government by guardians undermines peoples' autonomy and thus their sense of responsibility and ability to learn. Democratic processes are superior as they promote freedom, individual and collective self-determination, and moral autonomy to an extent as no other forms of political regimes (Dahl, 1989). Recently, the debate over how to solve the trade-off between providing security and freedom in democracies gained prominence during the aftermath of the terrorist attacks of 9/11. As a response, Bruce Ackerman proposes a so-called emergency constitution, which enables the government to take extraordinary actions in the short run to fight against a next attack, while safeguarding human rights and without generating insuperable long-term pathologies (Ackerman, 2006).

With the COVID-19 still spreading, countries have to make difficult choices between protecting civil liberties and minimizing the risk of deaths. The coercive power of some non-democratic countries 
may have provided them with an early advantage in reducing deaths in this pandemic. ${ }^{3}$ However, the freedom of information and research available in democratic countries might help them over time to reverse the autocratic advantage we document in this paper. Therefore, we hope that our paper reignites the broader debate about the trade-off that democratic societies must grapple with - restricting social and economic interactions to secure the public health during emergencies while maintaining the civil liberties that define liberal democracy.

The paper proceeds as follows. In the next section, we provide a brief overview of the COVID-19 crisis. The third section presents the data that we use in the study. In the fourth and fifth sections, we present our main analyses, which uses country-level data on the number of confirmed deaths from the Oxford COVID-19 Government Response Tracker (OxCGRT) as our dependent variable. First, looking at cross-sectional data we regress total per capita deaths on some standard measures of the democratic quality of political institutions. We also pursue an instrumental variable strategy on the cross-sectional data in which we use a "neighborhood" instrument, in the spirit of Acemoglu et al. (2019). We are careful about trying to rule out the possibility that the result is not capturing underreporting of deaths by less democratic countries. Second, we exploit the (daily) time dimension of the OxCGRT data, employing survival analysis to estimate whether or not democracy had an impact on the speed with which the crisis led to deaths in the countries. ${ }^{4}$ Third, using interaction models with the repeated cross-section data, we investigate the extent to which democratic institutions impacted the effectiveness of policy interventions to reduce deaths. The final section discusses some rationalizations and theoretical implications of our results.

\section{Background}

An outbreak of pneumonia emerged in Wuhan City, Hubei province in China in December 2019. The cause was identified as a novel coronavirus, which the World Health Organization (WHO) named

\footnotetext{
${ }^{3}$ Schwartz (2012) argues that there may be an "authoritarian advantage" in policy responses to pandemics in their comparative analysis of how the SARS outbreak was dealt with by China and Taiwan.

${ }^{4}$ Our survival analysis is focused on measuring time until countries experience a COVID-19 death after recording their first confirmed case. The survival model accounts for the fact that the data on COVID-19 deaths is censored, i.e. the cases of future deaths are not yet observed in the data.
} 
COVID-19 in February 2020. COVID-19, a relative of severe acute respiratory syndrome (SARS), induces symptoms such as dry cough, sore throat, and fever and in a small fraction of the cases leads to severe pneumonia requiring intensive care support, especially among the elderly and patients with multiple comorbidities (Sohrabi et al., 2020).

The infection spread via human-to-human transmission and its reach escalated due to national and international travel (Heymann and Shindo, 2020). The WHO declared by the end of January that the coronavirus outbreak constituted a public health emergency of international concern and characterized COVID-19 as a pandemic in early March (WHO, 2020b).

On 27 April 2020, there was around of 2.9 million confirmed COVID-19 cases, and close to 206 thousand deaths recorded globally (Coronavirus Resource Center, 2020; Dong, Du and Gardner, 2020). The highest numbers of confirmed cases come from the US, Spain, Italy, France, Germany, UK, China and Iran and the incidence of the virus is still rising globally, though at a different pace across countries. While some, such as China, Singapore, Taiwan, and Hong Kong seem to have contained the outbreak, most other countries (i.e. in Europe and the United States) are yet fighting to control COVID-19.

Governments responded to COVID-19 differently, with measures introduced varying greatly, both in their stringency and in their timing. The Chinese experience together with the WHO recommendations point to the role of quarantine, social distancing and isolation of infected populations in reducing transmission (WHO, 2020a; Anderson et al., 2020). Accordingly, some of the most common social measures include some level of travel and movement restrictions, bans on public gatherings, school and workplace closings (distance learning and teleworking from home), and closures of non-essential facilities and services. Given that there is no vaccine or an antiviral drug in the early days of the pandemic, the widely declared aim of these social distancing measures is to flatten the epidemiological curve to avoid surpassing the capacities of healthcare systems (Anderson et al., 2020). Parallel to social measures, governments tended to invest extra funds in health care, and they implemented testing and contact tracing protocols to stop chains of transmission. The latter two policies may become especially important once social measures are lifted to avert a resurgence of the virus (WHO, 2020a).

The scale and nature of these policy responses and their intrusion into private lives are unprece- 
dented, especially in democratic regimes, where citizens are less subservient to the ruling power and where individual rights are institutionally protected. Thus, it is interesting to compare how democratic and less democratic regimes fared in terms of death toll and effectiveness of policy responses in the early stages of the COVID-19 crisis.

\section{Data}

\subsection{Data source and country coverage}

Our main data source is the Oxford COVID-19 Government Response Tracker (OxCGRT) as of 9 April 2020. The OxCGRT is an ongoing data collection project, which covers systematic information on several different common policy responses governments have taken as the COVID-19 virus has spread, and a common aggregate score called the Stringency Index (Hale et al., 2020b). We make use of the OxCGRT longitudinal data base covering daily updates on policy responses and confirmed COVID-19 cases and deaths from 1 January 2020 until 9 April 2020. We complement the OxCGRT with measures of democratic institutions and a handful of economic and social characteristics of countries. After merging all our data sources, we end up with 106 countries covering all major geographical regions.

\subsection{Variables}

Our main dependent variable is the number of deaths per capita due to COVID-19 in a country, based on the number of confirmed deaths from OxCGRT. The other dependent variable we study is the Stringency Index, which is a composite measure of the stringency of government responses to COVID19 , running on a scale from 0 to 100 , based on the presence and stringency of seven policy measures. ${ }^{5}$

The main explanatory variable of interest is the Level of Democracy (an average of the Freedom House and Polity indicator), which ranges from 0-10, where 0 is least democratic and 10 most demo-

\footnotetext{
${ }^{5}$ The stringency index is a composite measure which is a simple additive score of seven response indicators - school closures, workplace closures, cancelling public events, closing public transport, public information campaigns, restricting internal movement, and international travel controls. The aim of the index is to have a general cross-national measure of policy stringency that allows for systematic comparisons across countries (Hale et al., 2020b).
} 
cratic (Teorell et al., 2020). In some specifications we use a binary indicator of democracy defined as 1 if the level of democracy is at least 5 in the country and 0 otherwise. As additional measures of quality of democratic institutions, we use the Political Corruption Index (running from less corrupt to more corrupt on a scale of 0 to 1) (Coppedge et al., 2020) and the Performance of Democratic Institutions indicator (measured on a scale from 1 to 10, where the higher the score, the better the performance) (Bertelsmann Stiftung, 2020).

We make use of several control variables that are potential confounders in our analysis: number of confirmed COVID-19 cases, real GDP per capita, percentage of tropical climate (percentage of the land surface area of each country with tropical climate), population density, a proxy for integration in the global economy (total trade as a share of GDP), a dummy for experiencing SARS (above 100 confirmed cases of SARS in the country in 2002-2003 based on the WHO), and the number of airports in the country.

We also control for variables indicative of the potential level of mis-reporting COVID-19 cases, such as an accountability and informational transparency index (Williams, 2015), the HRV transparency index measuring the availability of credible aggregate economic data that a country discloses (Hollyer, Rosendorff and Vreeland, 2014), and the number of total COVID-19 tests per 1000 people in a country (Joe Hasell and Roser, 2020). Additionally, we explore variables that are characterizing state capacity: an estimate of government effectiveness (Kaufmann, Kraay and Mastruzzi, 2011), an indicator of quality of government (PRS, 2019), and a state fragility index (Marshall, Gurr and Jaggers, 2017).

Another group of independent variables indicates whether governments introduced certain measures in response to COVID-19 and suggests the stringency of these policies, such as school closings, workplace closings, cancelling of public events, closing public transport, public information campaigns, restrictions on internal movement, international travel controls, fiscal measures, monetary measures, investment in health care and vaccines, testing and contact tracing (Hale et al., 2020b). For a detailed definition of each variable, their sources and descriptive statistics please see the Online Appendix. 


\section{Political regimes and deaths}

\subsection{Cross-section analysis: Ordinary Least Squares}

We begin with a cross-section analysis, where we consider the total deaths per capita at the end date of our data collection. We take the natural log transformation of deaths per capita due to the strong right skew of that variable. ${ }^{6}$ Technically, we estimate the following regression with OLS:

$$
Y_{i}=\beta_{0}+\beta_{1} D_{i}+X_{i}^{\prime} \Gamma+\epsilon_{i}
$$

where $D_{i}$ represents the political institutional measure for country $i, X_{i}$ is a vector of controls, and $\epsilon_{i}$ is the error term. In the vector of controls we include measures for the actual spread of the virus (log of confirmed cases and days since the first confirmed case), vulnerability to spread of the virus (economic integration in the world economy, percentage of land that is tropical, and number of airports), economic development level and recent experience with the SARS pandemic.

Results in Table 1 show that there are highly statistically significant cross-country correlations between political institutional measures and deaths per capita. In Panel $\mathrm{A}$, we present the bivariate correlations, while in Panel B we include the vector of control variables. The top-line result in column 1 of Panel B indicates that a one unit increase in the democracy index is associated with a 13\% increase in deaths per capita. Appendix Figure A.3 demonstrates that the result is not being driven by one country, in particular. ${ }^{7}$ Appendix Table A.7 demonstrates that the result is not being driven by our choice of dependent variable. ${ }^{8}$ That result is confirmed with the binary measure of democracy (in column 2) where we estimate that countries with democracy scores equal or above 5 have experienced $71 \%$ more deaths per capita than countries with scores below 5 . The performance of democratic in-

\footnotetext{
${ }^{6}$ We divide the total deaths by the population (in millions) and then take the log of deaths per capita +1 , so that we don't lose the observations for which there were reported cases, but no deaths. Appendix Figure A.2 shows histograms for the raw data and the log transformed data. Results are robust to the use of either measure.

${ }^{7}$ The figure shows the coefficient point estimate is quite stable at around 0.13 and highly statistically significant as we jack-knife the following potentially influential countries: Belgium, China, France, Germany, Iran, Italy, Netherlands, UK, and USA.

${ }^{8}$ There we show that higher democracy index scores are positively and statistically significantly correlated with logged per capita deaths weighted by the fraction of population over age 65, logged total deaths, deaths per capita, deaths per capita weighted by the fraction of population over age 65 , the death rate among confirmed cases and the logged death rate.
} 
Table 1: Cross-section OLS regressions - logged COVID-19 Deaths per capita

\begin{tabular}{|c|c|c|c|c|}
\hline \multicolumn{5}{|l|}{ Dependent variable: logged COVID-19 Deaths per capita } \\
\hline Panel A: Bivariate regressions & (1) & (2) & (3) & (4) \\
\hline Level of Democracy (Freedom House/Imputed Polity) & $\begin{array}{c}0.24^{* * *} \\
(0.04)\end{array}$ & & & \\
\hline Level of Democracy (binary indicator) & & $\begin{array}{c}0.99^{* * * *} \\
(0.25)\end{array}$ & & \\
\hline Political Corruption Index & & & $\begin{array}{c}-2.89^{* * *} \\
(0.42)\end{array}$ & \\
\hline Performance of Democratic Institutions & & & & $\begin{array}{l}0.08^{*} \\
(0.04)\end{array}$ \\
\hline $\mathrm{R}^{2}$ & 0.2265 & 0.0821 & 0.3382 & 0.0600 \\
\hline $\mathrm{N}$ & 104 & 104 & 104 & 78 \\
\hline Panel B: Multiple regressions & (1) & (2) & (3) & (4) \\
\hline Level of Democracy (Freedom House/Imputed Polity) & $\begin{array}{c}0.13^{* * *} \\
(0.03)\end{array}$ & & & \\
\hline Level of Democracy (binary indicator) & & $\begin{array}{c}0.71^{* * * *} \\
(0.18)\end{array}$ & & \\
\hline Political Corruption Index & & & $\begin{array}{c}-1.51^{* * *} \\
(0.39)\end{array}$ & \\
\hline Performance of Democratic Institutions & & & & $\begin{array}{c}0.05 \\
(0.03)\end{array}$ \\
\hline Log (Confirmed cases) & $\begin{array}{c}0.53^{* * *} \\
(0.07)\end{array}$ & $\begin{array}{c}0.56^{* * * *} \\
(0.06)\end{array}$ & $\begin{array}{c}0.57^{* * *} \\
(0.07)\end{array}$ & $\begin{array}{c}0.36^{* * * *} \\
(0.07)\end{array}$ \\
\hline Log (Real GDP per capita) & $\begin{array}{c}0.02 \\
(0.11)\end{array}$ & $\begin{array}{c}0.08 \\
(0.12)\end{array}$ & $\begin{array}{l}-0.10 \\
(0.13)\end{array}$ & $\begin{array}{c}0.08 \\
(0.09)\end{array}$ \\
\hline Percentage tropical climate in 2012 & $\begin{array}{l}-0.00 \\
(0.00)\end{array}$ & $\begin{array}{l}-0.00 \\
(0.00)\end{array}$ & $\begin{array}{c}0.00 \\
(0.00)\end{array}$ & $\begin{array}{c}0.00 \\
(0.00)\end{array}$ \\
\hline Population density & $\begin{array}{l}-0.00^{*} \\
(0.00)\end{array}$ & $\begin{array}{l}-0.00^{*} \\
(0.00)\end{array}$ & $\begin{array}{l}-0.00^{*} \\
(0.00)\end{array}$ & $\begin{array}{l}-0.00 \\
(0.00)\end{array}$ \\
\hline Trade (\% of GDP) & $\begin{array}{l}0.00^{*} \\
(0.00)\end{array}$ & $\begin{array}{c}0.00^{* *} \\
(0.00)\end{array}$ & $\begin{array}{c}0.00^{* *} \\
(0.00)\end{array}$ & $\begin{array}{c}0.00 \\
(0.00)\end{array}$ \\
\hline SARS & $\begin{array}{l}-0.10 \\
(0.38)\end{array}$ & $\begin{array}{l}-0.08 \\
(0.45)\end{array}$ & $\begin{array}{l}-0.43 \\
(0.47)\end{array}$ & $\begin{array}{c}0.21 \\
(0.37)\end{array}$ \\
\hline Log (airports) & $\begin{array}{c}-0.21^{* *} \\
(0.07)\end{array}$ & $\begin{array}{c}-0.21^{* *} \\
(0.07)\end{array}$ & $\begin{array}{l}-0.15^{*} \\
(0.07)\end{array}$ & $\begin{array}{c}-0.11+ \\
(0.06)\end{array}$ \\
\hline Days since first case & $\begin{array}{c}-0.02^{* *} \\
(0.01)\end{array}$ & $\begin{array}{c}-0.02^{* *} \\
(0.01)\end{array}$ & $\begin{array}{c}-0.02^{* * * *} \\
(0.01)\end{array}$ & $\begin{array}{c}-0.02^{* * * *} \\
(0.01)\end{array}$ \\
\hline $\mathrm{R}^{2}$ & 0.7128 & 0.6959 & 0.7047 & 0.5659 \\
\hline $\mathrm{N}$ & 104 & 104 & 104 & 78 \\
\hline
\end{tabular}

stitutions indicator points in a similar direction (in column 4). Interestingly, there is also a negative correlation with the control of corruption. Countries that score worse in terms of political corruption also have lower deaths per capita (column 3). While the results in columns 3 go in the same direction as the democracy level result (the institutional variables are highly correlated), they also indicate the possibility of under-reporting of deaths in countries with more opaque governments. We return to 
this issue in section 4.3 .

As for other controls, naturally the log of confirmed cases is highly statistically significant and positively correlated with deaths. In some specifications, economic development level is negatively correlated with deaths, as is past experience with the SARS epidemic. Economic globalization, measured by the openness to international trade is statistically significant and positive. Surprisingly, the number of airports and the days since the first case both correlate negatively with COVID-19 deaths in Table $1 .^{9}$

\subsection{Cross-section analysis: Two-Stage Least Squares}

The method of instrumental variables provides a general solution to the problem of endogenous explanatory variables, allowing for consistent estimation when explanatory variables are correlated with the error term in a regression model. The endogeneity - or correlation between explanatory variables and the error term - may occur because of reverse causality, omitted variable bias, and non-random measurement errors (Wooldridge, 2002, p. 89-96). We believe that reverse causality is a minor problem in our data, since it is to soon to observe the impact COVID-19 will have on political regimes. ${ }^{10}$ On the other hand, instrumental variables help us mitigate problems related to omitted variable bias and measurement errors. For instance, dictatorships might under-report the number of COVID-19 cases or economic data because of the lack of state capacity, or a more constrained public opinion. Consequently, dictatorships are not better at fighting the virus, just bad at reporting information. Similarly, dictatorships might have higher number of infectious diseases due to lower levels of public health information and sanitary measures (Jiang et al., 2020), and our findings might underestimate the effect of political regimes on reducing deaths. In our case, as the results of the instrumental variable present the same sign and statistical significance of other methods present in the paper, it can also be considered a robustness check of the relationship of interest.

\footnotetext{
${ }^{9}$ We note that both the number of airports and days since the first case have a positive pairwise correlation coefficient with logged per capita deaths, however.

${ }^{10}$ We already know that countries such as Hungary, Poland, Turkey and Russia are adopting anti-democratic legislation. In Hungary, for example, the Parliament passed a law on 31 March, 2020 that allows the government to rule by decree, suspend the Parliament and repeal any existing law, indefinitely. However, we cannot observe these changes in our data.
} 
We construct "neighborhood" instruments for our political institution variables. Following the spirit of the identification strategies of Acemoglu et al. (2019) and Dorsch and Maarek (2019), we calculate the regional average values for the political institutional measures, not including the country for which the neighborhood effect is being calculated. More formally, for a country-specific democracy indicator, $D_{i}$, and denoting the set of countries in a given region by $I_{i}$, we define the instrument for country $i$ as

$$
Z_{i}=\frac{1}{I_{i}-1} \sum_{i^{\prime} \in I_{i}} D_{i^{\prime}}
$$

for $i^{\prime} \neq i$. In other words, the instrument $Z_{i}$ is the jack-knifed average of democracy in a region, leaving out the own-country observation. ${ }^{11}$

We then proceed to estimate the impact of democratic institutions on deaths per capita using TwoStage Least Squares. In the first stage, we estimate the instrumented variation in the level of democracy:

$$
D_{i}=\alpha_{0}+\alpha_{1} Z_{i}+X_{i}^{\prime} \Theta+v_{i}
$$

We then use the fitted values from equation 3 to estimate the second stage relationship:

$$
Y_{i}=\beta_{0}+\beta_{1}^{I V} \widehat{D_{i}}+X_{i}^{\prime} \Gamma+\epsilon_{i}
$$

where $\widehat{D_{i}}$ is orthogonal to $\epsilon_{i}$ if our instrument $Z_{i}$ is valid. We have constructed the neighborhood instrument for each of the five different institutional measures that we evaluate. First-stage F-statistics are well above the rule-of-thumb criteria of 10 , so we are confident in the strength of the instruments. First-stage regressions in Appendix Table A. 5 show that the instruments are significant at the 0.1 percent level in all specifications. ${ }^{12}$

\footnotetext{
${ }^{11}$ We use the regional coding from Hadenius and Teorell (2007), which are Eastern Europe \& post Soviet Union, Latin America, North Africa \& Middle East, Sub-Saharan Africa, Western Europe \& North America, East Asia, South Asia, the Pacific, and the Caribbean.

${ }^{12}$ The quality of political institutions in regional countries may influence the death rate through their impact on regional movement of people and goods, which would violate the exclusion restriction. However, controlling for economic integration and airports should, to some extent, alleviate these concerns. Moreover, including the number of confirmed cases controls for the spread of the virus through such channels.
} 
Table 2: Cross-section Two-Stage Least Squares regressions - logged COVID-19 Deaths per capita

\begin{tabular}{|c|c|c|c|c|}
\hline & (1) & (2) & (3) & (4) \\
\hline \multicolumn{5}{|l|}{ Dependent variable: logged COVID-19 Deaths per capita } \\
\hline Level of Democracy (Freedom House/Imputed Polity) & $\begin{array}{c}0.30^{* * *} \\
(0.06)\end{array}$ & & & \\
\hline Level of Democracy (binary indicator) & & $\begin{array}{c}2.49^{* * *} \\
(0.63)\end{array}$ & & \\
\hline Political Corruption Index & & & $\begin{array}{c}-6.12^{* * *} \\
(1.42)\end{array}$ & \\
\hline Performance of Democratic Institutions & & & & $\begin{array}{c}0.03 \\
(0.08)\end{array}$ \\
\hline Log (Confirmed cases) & $\begin{array}{c}0.47^{* * *} \\
(0.08)\end{array}$ & $\begin{array}{c}0.51^{* * *} \\
(0.09)\end{array}$ & $\begin{array}{c}0.54^{* * *} \\
(0.10)\end{array}$ & $\begin{array}{c}0.37^{* * *} \\
(0.07)\end{array}$ \\
\hline Log (Real GDP per capita) & $\begin{array}{l}-0.07 \\
(0.12)\end{array}$ & $\begin{array}{c}0.05 \\
(0.16)\end{array}$ & $\begin{array}{c}-0.70^{* *} \\
(0.24)\end{array}$ & $\begin{array}{c}0.08 \\
(0.08)\end{array}$ \\
\hline Percentage tropical climate in 2012 & $\begin{array}{l}-0.00 \\
(0.00)\end{array}$ & $\begin{array}{l}-0.00 \\
(0.00)\end{array}$ & $\begin{array}{c}0.01 \\
(0.00)\end{array}$ & $\begin{array}{c}0.00 \\
(0.00)\end{array}$ \\
\hline Population density & $\begin{array}{l}-0.00 \\
(0.00)\end{array}$ & $\begin{array}{l}-0.00 \\
(0.00)\end{array}$ & $\begin{array}{l}-0.00 \\
(0.00)\end{array}$ & $\begin{array}{l}-0.00 \\
(0.00)\end{array}$ \\
\hline Trade (\% of GDP) & $\begin{array}{c}0.00 \\
(0.00)\end{array}$ & $\begin{array}{c}0.00 \\
(0.00)\end{array}$ & $\begin{array}{c}0.00 \\
(0.00)\end{array}$ & $\begin{array}{c}0.00 \\
(0.00)\end{array}$ \\
\hline SARS & $\begin{array}{c}0.16 \\
(0.40)\end{array}$ & $\begin{array}{c}0.48 \\
(0.47)\end{array}$ & $\begin{array}{l}-0.83 \\
(0.53)\end{array}$ & $\begin{array}{c}0.18 \\
(0.39)\end{array}$ \\
\hline Log (airports) & $\begin{array}{c}-0.27^{* * *} \\
(0.07)\end{array}$ & $\begin{array}{c}-0.31^{* * *} \\
(0.09)\end{array}$ & $\begin{array}{l}-0.11 \\
(0.11)\end{array}$ & $\begin{array}{c}-0.11+ \\
(0.06)\end{array}$ \\
\hline Days since first case & $\begin{array}{l}-0.01 \\
(0.01)\end{array}$ & $\begin{array}{l}-0.01 \\
(0.01)\end{array}$ & $\begin{array}{c}-0.03^{* *} \\
(0.01)\end{array}$ & $\begin{array}{c}-0.02^{* *} \\
(0.01)\end{array}$ \\
\hline First-stage C-D F-stat & 46.688 & 24.291 & 19.976 & 10.703 \\
\hline First-stage K-P F-stat & 41.155 & 24.078 & 24.205 & 8.886 \\
\hline $\mathrm{N}$ & 104 & 104 & 104 & 78 \\
\hline
\end{tabular}

The results in Table 2 suggest that OLS had under-estimated the impact of political institutions on per capita deaths. The top-line result from the 2SLS analysis is that a one point increase in the democracy score is associated with a 30\% increase in COVID-19 deaths per capita over the early stages of the crisis. This suggests that estimates about the effect of political institutions from other models that we present in the paper are likely to be lower bound estimations of the actual effect.

We have conducted several sensible robustness tests on these 2SLS results. Appendix Table A.6 shows reduced form regressions, where we use OLS to estimate the impact of the instruments directly on the outcome variable. Appendix Figure A.3 shows that the result is not being driven by any specific countries. Appendix Table A.7 demonstrates that the result is not being driven by our choice of depen- 
dent variable. ${ }^{13}$ Appendix Table A. 8 demonstrates that coefficient estimates are quite similar when the two-stage regressions use a Tobit IV estimator. ${ }^{14}$

\subsection{Cross-section analysis: Mis-reporting}

A major concern is that the result may be picking up the possibility that less democratic countries are systematically under-reporting deaths. We see two possibilities for how this may occur. The first is that the death data is mis-reported for political reasons. The second is that governments may be underreporting simply because they are not testing sufficiently and cannot differentiate between deaths that are related to, for example, heart conditions or COVID-related complications.

To address the first possibility, we include two measures of government transparency. In Table 3, which reports OLS and 2SLS results for the democracy index, we first control for information transparency and accountability with a transparency index by Williams (2015) and second for transparency of governmental reporting of economic data using the index of Hollyer, Rosendorff and Vreeland (2014). We suppose that governments who mis-report information and economic data for political reasons would also mis-report data for COVID-19 deaths.

To address the second possibility, we include controls for COVID-19 testing, the number of COVID19 tests per 1000 people ${ }^{15}$ and the ratio of total confirmed cases to total tests. If governments underreport due to lack of information, these controls should pick that up. The testing data is only available for 49 countries (for which we also have the other controls), but the results are stable to the introduction of these important controls despite the different samples. Particularly with the OLS estimations, the results are quite consistent with our baseline estimations (where $\hat{\beta}_{1}=0.13$ ). ${ }^{16}$ The 2 SLS estimates remain statistically significantly positive as well with these additional controls.

\footnotetext{
${ }^{13}$ There we show that higher democracy index scores are positively and statistically significantly correlated with logged per capita deaths weighted by the fraction of population over age 65, logged total deaths, deaths per capita, and deaths per capita weighted by the fraction of the population over age 65.

${ }^{14}$ Moreover, the OLS and 2SLS results are also robust to the inclusion of further controls (eg, inequality coefficients and demographic measures) though including them reduces the size of our sample, regional fixed effects, and clustering standard errors by region.

${ }^{15}$ We have taken the log of the testing variable as it is strongly skewed to the right.

${ }^{16}$ We have also considered dropping the least (and most) transparent countries from the sample, as these are the most likely to be under-reporting (over-reporting). Appendix Table A.4 drops countries that are in the lowest decile and highest deciles according to the following: the two transparency indicators and the tests per 1000 measure.
} 
Table 3: Cross-section regressions - controlling for under-reporting

\begin{tabular}{|c|c|c|c|c|c|c|c|c|}
\hline & \multicolumn{4}{|c|}{ Ordinary Least Squares } & \multicolumn{4}{|c|}{ Two-Stage Least Squares } \\
\hline & (1) & (2) & (3) & (4) & (5) & (6) & (7) & (8) \\
\hline \multicolumn{9}{|l|}{ Dependent Variable: logged COVID-19 Deaths per capita } \\
\hline Level of Democracy (Freedom House/Imputed Polity) & $\begin{array}{l}0.16^{* *} \\
(0.05)\end{array}$ & $\begin{array}{c}0.09^{* *} \\
(0.04)\end{array}$ & $\begin{array}{l}0.15^{*} \\
(0.07)\end{array}$ & $\begin{array}{l}0.10+ \\
(0.06)\end{array}$ & $\begin{array}{l}0.92^{* * *} \\
(0.33)\end{array}$ & $\begin{array}{c}0.34^{* * * *} \\
(0.09)\end{array}$ & $\begin{array}{l}0.56^{* *} \\
(0.20)\end{array}$ & $\begin{array}{l}0.56^{*} \\
(0.22)\end{array}$ \\
\hline Information and accountability transparency index & $\begin{array}{l}-0.01 \\
(0.02)\end{array}$ & & & & $\begin{array}{l}-0.18^{*} \\
(0.07)\end{array}$ & & & \\
\hline Economic data transparency index & & $\begin{array}{c}0.10 \\
(0.07)\end{array}$ & & & & $\begin{array}{l}-0.09 \\
(0.09)\end{array}$ & & \\
\hline Log (Tests per 1000) & & & $\begin{array}{l}0.38^{*} \\
(0.15)\end{array}$ & & & & $\begin{array}{l}0.61^{* *} \\
(0.22)\end{array}$ & \\
\hline Confirmed cases / Tests & & & & $\begin{array}{l}6.39^{* *} \\
(2.16)\end{array}$ & & & & $\begin{array}{c}5.19^{* *} \\
(1.80)\end{array}$ \\
\hline Log (Confirmed cases) & $\begin{array}{c}0.54^{* * *} \\
(0.07)\end{array}$ & $\begin{array}{c}0.52^{\text {*** }} \\
(0.07)\end{array}$ & $\begin{array}{c}0.70^{* * *} \\
(0.12)\end{array}$ & $\begin{array}{c}0.46^{* *} \\
(0.14)\end{array}$ & $\begin{array}{c}0.63^{* * *} \\
(0.11)\end{array}$ & $\begin{array}{c}0.52^{* * *} \\
(0.09)\end{array}$ & $\begin{array}{c}0.70^{* * *} \\
(0.14)\end{array}$ & $\begin{array}{r}0.50^{* *} \\
(0.18)\end{array}$ \\
\hline Log (Real GDP per capita) & $\begin{array}{c}0.04 \\
(0.11)\end{array}$ & $\begin{array}{l}-0.02 \\
(0.12)\end{array}$ & $\begin{array}{l}-0.16 \\
(0.35)\end{array}$ & $\begin{array}{c}0.30 \\
(0.24)\end{array}$ & $\begin{array}{c}0.36 \\
(0.23)\end{array}$ & $\begin{array}{l}-0.21 \\
(0.16)\end{array}$ & $\begin{array}{c}-1.02+ \\
(0.59)\end{array}$ & $\begin{array}{l}-0.40 \\
(0.53)\end{array}$ \\
\hline Percentage tropical climate in 2012 & $\begin{array}{l}-0.00 \\
(0.00)\end{array}$ & $\begin{array}{l}-0.00 \\
(0.00)\end{array}$ & $\begin{array}{l}0.01+ \\
(0.00)\end{array}$ & $\begin{array}{l}-0.00 \\
(0.00)\end{array}$ & $\begin{array}{l}-0.00 \\
(0.00)\end{array}$ & $\begin{array}{l}-0.00 \\
(0.00)\end{array}$ & $\begin{array}{l}0.01+ \\
(0.01)\end{array}$ & $\begin{array}{c}0.00 \\
(0.01)\end{array}$ \\
\hline Population density & $\begin{array}{l}-0.00^{*} \\
(0.00)\end{array}$ & $\begin{array}{l}-0.00^{*} \\
(0.00)\end{array}$ & $\begin{array}{c}0.00 \\
(0.00)\end{array}$ & $\begin{array}{l}-0.00 \\
(0.00)\end{array}$ & $\begin{array}{l}-0.00 \\
(0.00)\end{array}$ & $\begin{array}{l}-0.00^{*} \\
(0.00)\end{array}$ & $\begin{array}{c}0.00 \\
(0.00)\end{array}$ & $\begin{array}{c}0.00 \\
(0.00)\end{array}$ \\
\hline Trade (\% of GDP) & $\begin{array}{c}0.01^{* *} \\
(0.00)\end{array}$ & $\begin{array}{c}0.01^{* *} \\
(0.00)\end{array}$ & $\begin{array}{l}0.00+ \\
(0.00)\end{array}$ & $\begin{array}{c}0.00 \\
(0.00)\end{array}$ & $\begin{array}{c}0.00 \\
(0.00)\end{array}$ & $\begin{array}{c}0.01^{* * *} \\
(0.00)\end{array}$ & $\begin{array}{l}0.01+ \\
(0.00)\end{array}$ & $\begin{array}{c}0.01 \\
(0.00)\end{array}$ \\
\hline SARS & $\begin{array}{l}-0.07 \\
(0.37)\end{array}$ & $\begin{array}{c}0.01 \\
(0.45)\end{array}$ & $\begin{array}{c}0.18 \\
(0.31)\end{array}$ & $\begin{array}{l}0.80^{*} \\
(0.31)\end{array}$ & $\begin{array}{c}0.44 \\
(0.69)\end{array}$ & $\begin{array}{c}0.13 \\
(0.51)\end{array}$ & $\begin{array}{l}-0.23 \\
(0.41)\end{array}$ & $\begin{array}{c}0.44 \\
(0.46)\end{array}$ \\
\hline $\log$ (airports) & $\begin{array}{c}-0.21^{* *} \\
(0.07)\end{array}$ & $\begin{array}{l}-0.17^{*} \\
(0.07)\end{array}$ & $\begin{array}{l}-0.19 \\
(0.12)\end{array}$ & $\begin{array}{l}-0.34^{*} \\
(0.14)\end{array}$ & $\begin{array}{c}-0.45^{* * *} \\
(0.13)\end{array}$ & $\begin{array}{l}-0.20^{*} \\
(0.08)\end{array}$ & $\begin{array}{l}-0.12 \\
(0.14)\end{array}$ & $\begin{array}{l}-0.30^{*} \\
(0.15)\end{array}$ \\
\hline Days since first case & $\begin{array}{c}-0.02^{* *} \\
(0.01)\end{array}$ & $\begin{array}{c}-0.02^{* *} \\
(0.01)\end{array}$ & $\begin{array}{l}-0.02^{*} \\
(0.01)\end{array}$ & $\begin{array}{l}-0.01 \\
(0.01)\end{array}$ & $\begin{array}{l}-0.01 \\
(0.01)\end{array}$ & $\begin{array}{l}-0.01 \\
(0.01)\end{array}$ & $\begin{array}{l}-0.01 \\
(0.01)\end{array}$ & $\begin{array}{c}0.00 \\
(0.02)\end{array}$ \\
\hline $\mathrm{R}^{2}$ & 0.7325 & 0.7319 & 0.7665 & 0.8083 & - & - & - & - \\
\hline First-stage C-D F-stat & - & - & - & - & 7.110 & 30.455 & 11.345 & 7.909 \\
\hline First-stage K-P F-stat & - & - & - & - & 5.533 & 27.070 & 5.147 & 4.421 \\
\hline $\mathrm{N}$ & 103 & 91 & 49 & 49 & 103 & 91 & 49 & 49 \\
\hline
\end{tabular}

\subsection{Survival models}

Here, we exploit the (daily) time dimension of the OxCGRT data and test the same specifications with survival analysis. Our main dependent variable is the length of time (number of days) it takes for a country to experience a COVID-19 related death after recording its first confirmed case of COVID-19. As the pandemic is still unfolding, the deaths data is "censured" and thus a survival model is well-suited for its analysis.

As a first step, we employ the Kaplan and Meier (Kaplan and Meier, 1958) non-parametric estimator of the survivor function $S_{t}$, which is the probability of survival past time $t$ or, equivalently, 
Figure 2: Deaths since the first case of COVID-19

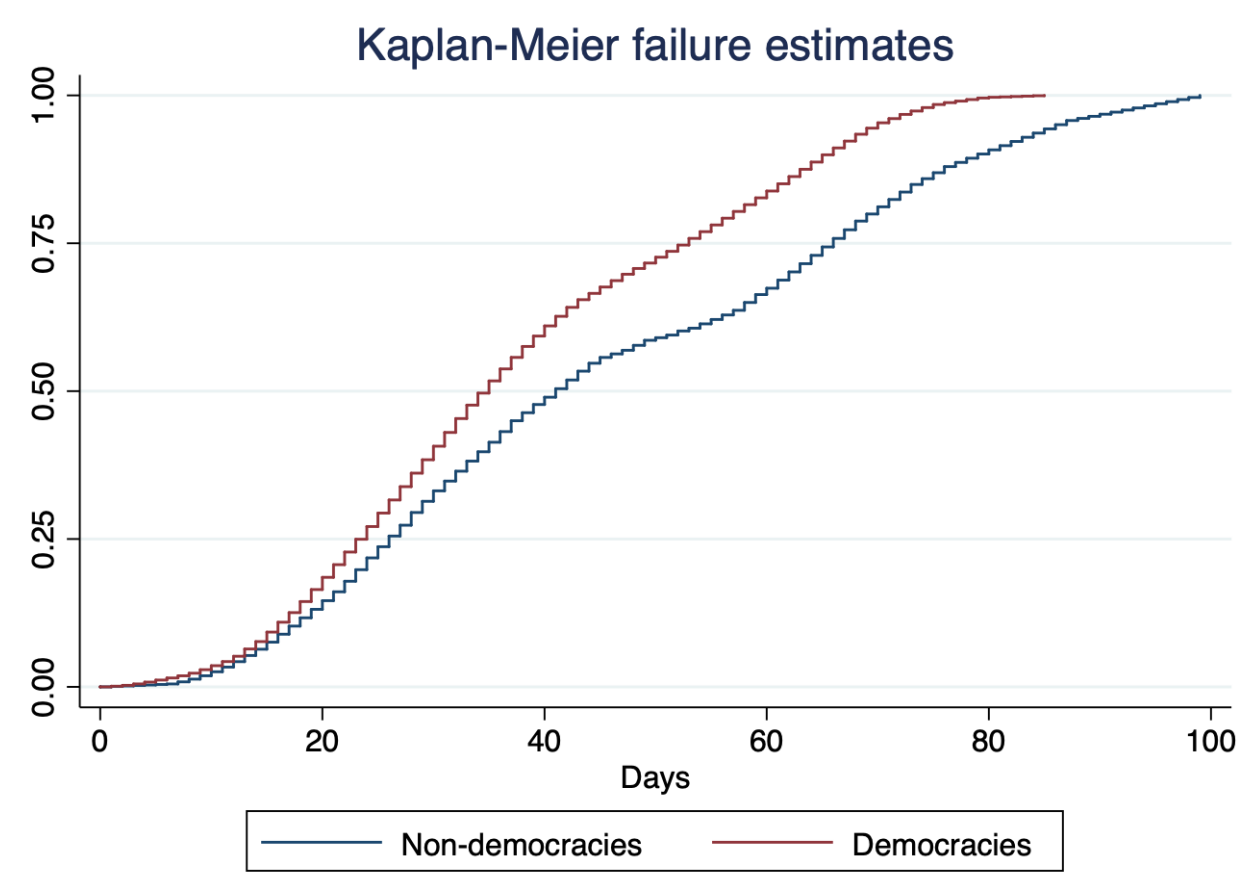

the probability of failing after $t .{ }^{17}$ For a data set with observed failure times, $t_{1}, \ldots, t_{k}$, where ${ }_{k}$ is the number of distinct failure times observed in the data, the Kaplan-Meir estimate at any time $t$ is given by:

$$
\hat{S}(t)=\prod_{j \mid t_{1} \leq t}\left(\frac{i_{j}-d_{j}}{i_{j}}\right),
$$

where $i_{j}$ is the number of entities at risk at time $t_{j}$ and $d_{j}$ is the number of failures at time $t_{j}$. The product is over all observed failure times less than or equal to $t$.

Figure 2 plots the Kaplan-Meier failures estimates (or the inverse of a survival function), where failure represents the first case of COVID-19 death after the first confirmed case of COVID-19 in a country at time $t .{ }^{18}$ To construct this figure, we use the binary measure of democracy (equal to one if the the democracy index is at least 5). At first, democratic and non-democratic countries display low probabilities of failure (experiencing a death) after their first case of COVID-19. The curve starts to increase rapidly after 10 days. Then, the probability of countries experiencing COVID-19 deaths over

\footnotetext{
${ }^{17}$ Table A.9 in the Online Appendix describes our survival data.

${ }^{18}$ We display the failure (death) curve instead of the survival curve for illustrative purposes.
} 
time is always higher in democracies than non-democracies. In the end of each curve, the probability of having a failure approaches one (after 75 days for non-democracies and after 90 days for democracies), which means that is very unlikely that countries would not experience at least one case of death.

A distinct characteristic of survival analysis is the estimation of a hazard rate. In this case, we are interested in the hazard rate that a country experiences a positive number of COVID-19 deaths since the first confirmed case in the country. Specifically, we estimate a Cox proportional hazards model (Cox, 1972) with the following baseline specification:

$$
h_{i}(t)=h_{0 i}(t) \exp \left(\beta_{1} X_{1}+\ldots+\beta_{k} X_{k}\right)
$$

where $h_{i}(t)$ is the hazard rate for country $i$ over time $(t)$ since the first confirmed case in the country. $X_{1}, \ldots, X_{b}$ are the country-level independent variables of our models. The Cox model provides estimates of $\beta_{1}, \ldots, \beta_{k}$, but provides no direct estimate of $h_{0 i}(t)-$ the baseline hazard. The function $h_{0 i}(t)$ is not directly estimated, but it is possible to recover cumulative hazard estimates and, from that, an estimate of the baseline survivor function instead of the density function used in non-censored cases. The Cox model has no intercept and an error term because it is absorbed into the baseline $h_{0 i}(t)$, and they are unidentifiable from the data.

Table 4 presents the results from Cox Hazards models. In all estimates, we present regression coefficients instead of hazard ratios - exponentiated coefficients. ${ }^{19}$ All specifications include the same (time-invariant) controls as in the cross-section analysis and include region fixed effects and robust standard errors. ${ }^{20}$

Exponentiated individual coefficients have the interpretation of the ratio of the hazards for a oneunit change in the corresponding independent variable. Therefore, in column 1, a one unit increase in the level of democracy increases the hazard ratio (risk that a country experiences a death since its first COVID-19 case) by $17 \%$ because $\exp (0.16)=1.17$. In column 2 , we employ a binary measure

\footnotetext{
${ }^{19}$ This is a difference only on how results are reported, not in the results themselves.

${ }^{20}$ These results are robust to several model specifications and different choices of standard errors. For the main paper, we choose relevant controls that maximize the number of countries in our data set, avoiding missing values. As most control variables are repeated country characteristics, we did not calculate cluster standard errors at country-level in most of our models.
} 
Table 4: Cox Proportional Hazards Model - COVID-19 Deaths

\begin{tabular}{|c|c|c|c|c|}
\hline & (1) & $(2)$ & (3) & (4) \\
\hline \multicolumn{5}{|c|}{ Dependent Variable: Hazard rate of COVID-19 death since the first case of COVID-19 } \\
\hline Level of Democracy (Freedom House/Imputed Polity) & $\begin{array}{c}0.16^{* * *} \\
(0.02)\end{array}$ & & & \\
\hline Level of Democracy (binary indicator) & & $\begin{array}{c}0.68^{* * *} \\
(0.07)\end{array}$ & & \\
\hline Political corruption index & & & $\begin{array}{c}0.78^{* * *} \\
(0.13)\end{array}$ & \\
\hline Performance of Democratic Institutions & & & & $\begin{array}{c}0.21^{* * *} \\
(0.02)\end{array}$ \\
\hline Information and accountability transparency index & $\begin{array}{c}-0.02^{* * * *} \\
(0.00)\end{array}$ & $\begin{array}{l}-0.01 \\
(0.00)\end{array}$ & $\begin{array}{c}0.02^{* * *} \\
(0.00)\end{array}$ & $\begin{array}{l}-0.00 \\
(0.01)\end{array}$ \\
\hline Log (Confirmed cases) & $\begin{array}{c}-0.21^{* * *} \\
(0.01)\end{array}$ & $\begin{array}{c}-0.21^{* * *} \\
(0.01)\end{array}$ & $\begin{array}{c}-0.21^{* * *} \\
(0.01)\end{array}$ & $\begin{array}{c}-0.32^{* * *} \\
(0.02)\end{array}$ \\
\hline Log (Real GDP per capita) & $\begin{array}{c}-0.59^{* * *} \\
(0.05)\end{array}$ & $\begin{array}{c}-0.58^{* * *} \\
(0.05)\end{array}$ & $\begin{array}{c}-0.53^{* * *} \\
(0.05)\end{array}$ & $\begin{array}{c}-0.60^{* * *} \\
(0.06)\end{array}$ \\
\hline Percentage tropical climate in 2012 & $\begin{array}{c}-0.01^{* * *} \\
(0.00)\end{array}$ & $\begin{array}{c}-0.01^{* * *} \\
(0.00)\end{array}$ & $\begin{array}{c}-0.01^{* * *} \\
(0.00)\end{array}$ & $\begin{array}{c}-0.00^{* *} \\
(0.00)\end{array}$ \\
\hline Population density (people per sq. km of land area) & $\begin{array}{c}0.00 \\
(0.00)\end{array}$ & $\begin{array}{l}0.00^{* *} \\
(0.00)\end{array}$ & $\begin{array}{l}0.00^{*} \\
(0.00)\end{array}$ & $\begin{array}{l}0.00^{*} \\
(0.00)\end{array}$ \\
\hline Trade (\% of GDP) & $\begin{array}{c}0.00 \\
(0.00)\end{array}$ & $\begin{array}{c}0.00 \\
(0.00)\end{array}$ & $\begin{array}{c}0.00 \\
(0.00)\end{array}$ & $\begin{array}{c}-0.01^{* * *} \\
(0.00)\end{array}$ \\
\hline SARS & $\begin{array}{l}-0.02 \\
(0.10)\end{array}$ & $\begin{array}{l}-0.13 \\
(0.10)\end{array}$ & $\begin{array}{c}-0.24^{*} \\
(0.10)\end{array}$ & $\begin{array}{c}0.96^{* * *} \\
(0.23)\end{array}$ \\
\hline Log (Airports) & $\begin{array}{c}-0.21^{* * *} \\
(0.02)\end{array}$ & $\begin{array}{c}-0.20^{* * * *} \\
(0.02)\end{array}$ & $\begin{array}{c}-0.22^{* * *} \\
(0.02)\end{array}$ & $\begin{array}{c}-0.13^{* * *} \\
(0.02)\end{array}$ \\
\hline Countries & 105 & 105 & 105 & 79 \\
\hline $\mathrm{N}$ & 4126 & 4126 & 4126 & 2742 \\
\hline
\end{tabular}

of democracy. Changing from non-democracy to democracy almost doubles the hazard rate. ${ }^{21}$ In column 3, we show that more corrupt countries present greater risk of failure (experiencing at least one death after its first case of COVID-19). Finally, in column 4, we observe that democratic institutions with higher performance were also at greater risk of COVID-19 deaths during the early stages of the COVID-19 crisis. $^{22}$

\footnotetext{
${ }^{21}$ In our estimates, the Cox partial likelihood is obtained by using Breslow's estimate of the baseline hazard function.

${ }^{22}$ Our sample is smaller in column 4 because we only consider democratic countries.
} 


\section{Political regimes, policy responses and deaths}

We have also investigated the extent to which more democratic countries have responded with more stringent policies and the extent to which policy responses were more effective in reducing deaths in democratic countries. First, we present a result with the cross-section data in section 5.1 and then return to the (daily) time-varying data in sections 5.2 and 5.3.

\subsection{Political regimes and policy stringency}

To begin, we return to the cross-section 2SLS estimation, but we now consider the index of policy stringency as the dependent variable (see the Data section). Consistent with the results concerning COVID-19 deaths, Table 5 demonstrates that more democratic countries pursued less stringent policy responses. Column 2 indicates that the democratic countries had stringency scores more than 18 points lower than non-democracies, on average. More political corruption was correlated with more stringent responses. On the whole, we can see that fewer constraints on the governments were associated with more stringent responses during the early stages of the crisis.

\subsection{Heterogeneous effects of policy responses: Linear interaction}

Returning to the time-varying data, we now investigate how individual policy responses correlated with deaths. In particular, we examine the extent to which there were heterogeneous effects of the policy responses on deaths across types of political institutions. Here we exploit the daily variation in the deaths and policy response data in a repeated cross-section OLS regression model with multiplicative interaction terms:

$$
Y_{i, t}=\beta_{0}+\beta_{1} D_{i}+\beta_{2} P_{i, t}+\beta_{3}\left(D_{i} * P_{i, t}\right)+X_{i}^{\prime} \Gamma+\epsilon_{i, t}
$$

where $Y_{i, t}$ is the outcome variable (logged deaths by COVID-19 per capita) in country $i$ on day $t, D_{i}$ is the political regime of country $i, P_{i, t}$ is the policy action of country $i$ on day $t$ (the treatment) and $D_{i} *$ $P_{i, t}$ is the interaction effect that we are interested in. Here, the political regime serves as a moderator 
Table 5: Cross-section Two-Stage Least Squares regressions

\begin{tabular}{|c|c|c|c|c|}
\hline & (1) & (2) & (3) & (4) \\
\hline \multicolumn{5}{|l|}{ Dependent Variable: Stringency Index } \\
\hline Level of Democracy (Freedom House/Imputed Polity) & $\begin{array}{l}-2.12^{*} \\
(1.01)\end{array}$ & & & \\
\hline Level of Democracy (Binary) & & $\begin{array}{c}-18.16+ \\
(9.45)\end{array}$ & & \\
\hline Political Corruption Index & & & $\begin{array}{l}43.87^{*} \\
(19.60)\end{array}$ & \\
\hline Performance of Democratic Institutions & & & & $\begin{array}{l}-0.45 \\
(1.93)\end{array}$ \\
\hline Log (Confirmed cases) & $\begin{array}{l}3.18^{*} \\
(1.53)\end{array}$ & $\begin{array}{l}2.97+ \\
(1.53)\end{array}$ & $\begin{array}{l}2.79+ \\
(1.59)\end{array}$ & $\begin{array}{c}2.63 \\
(2.00)\end{array}$ \\
\hline Log (Real GDP per capita) & $\begin{array}{l}-1.23 \\
(2.28)\end{array}$ & $\begin{array}{l}-1.93 \\
(2.47)\end{array}$ & $\begin{array}{c}3.59 \\
(3.63)\end{array}$ & $\begin{array}{l}-1.59 \\
(2.35)\end{array}$ \\
\hline Percentage tropical climate in 2012 & $\begin{array}{l}-0.03 \\
(0.05)\end{array}$ & $\begin{array}{l}-0.02 \\
(0.05)\end{array}$ & $\begin{array}{l}-0.08 \\
(0.06)\end{array}$ & $\begin{array}{l}-0.04 \\
(0.05)\end{array}$ \\
\hline Population density & $\begin{array}{l}-0.00 \\
(0.00)\end{array}$ & $\begin{array}{l}-0.00 \\
(0.00)\end{array}$ & $\begin{array}{l}-0.00 \\
(0.00)\end{array}$ & $\begin{array}{l}-0.00 \\
(0.00)\end{array}$ \\
\hline Trade (\% of GDP) & $\begin{array}{c}0.03 \\
(0.05)\end{array}$ & $\begin{array}{c}0.04 \\
(0.05)\end{array}$ & $\begin{array}{c}0.04 \\
(0.05)\end{array}$ & $\begin{array}{c}0.05 \\
(0.06)\end{array}$ \\
\hline SARS & $\begin{array}{l}-14.98 \\
(14.02)\end{array}$ & $\begin{array}{l}-17.18 \\
(14.22)\end{array}$ & $\begin{array}{c}-7.29 \\
(14.32)\end{array}$ & $\begin{array}{c}-29.12^{* *} \\
(11.27)\end{array}$ \\
\hline $\log$ (airports) & $\begin{array}{l}-0.93 \\
(1.51)\end{array}$ & $\begin{array}{l}-0.57 \\
(1.65)\end{array}$ & $\begin{array}{l}-2.07 \\
(1.71)\end{array}$ & $\begin{array}{l}-0.72 \\
(1.78)\end{array}$ \\
\hline Days since first case & $\begin{array}{l}-0.06 \\
(0.11)\end{array}$ & $\begin{array}{l}-0.06 \\
(0.12)\end{array}$ & $\begin{array}{c}0.04 \\
(0.12)\end{array}$ & $\begin{array}{c}0.07 \\
(0.18)\end{array}$ \\
\hline First-stage C-D F-stat & 40.597 & 20.463 & 20.530 & 8.758 \\
\hline First-stage K-P F-stat & 36.992 & 20.962 & 25.353 & 7.587 \\
\hline $\mathrm{N}$ & 105 & 105 & 105 & 80 \\
\hline
\end{tabular}

- a variable that affects the direction and strength of the policy treatment effect. As before, $X_{i}$ is the vector of control variables.

Table 6 presents the results. We employ the (logged) COVID-19 deaths per capita as the dependent variable and our standard vector of controls. All models include region fixed effects and robust standard errors. ${ }^{23}$ To save space, we do not display the control variables, since all results are comparable with other models presented in this study. We consider the following policy response variables: school closing (SC), workplace closing (WPC), cancel public events (CPE), close public transport (CPT), public information campaigns (PIC), restrict internal movement (RIM), international travel controls (ITC),

\footnotetext{
${ }^{23}$ Again, the results are robust to several model specifications and different choices of standard errors.
} 
fiscal measures (FM), monetary measures (MM), investment in health care (IH), investment in vaccines (IV), testing framework (TF), and contact tracing (CT).

As we can see in Table 6, all significant interactions are estimated to have a positive sign, meaning the policy responses were less effective in reducing deaths in countries with higher democracy scores. To understand the marginal effect of a policy, $\beta_{2}+\beta_{3} \times D_{i}$, take for example, the closing public events policy response variable (column 3). There the marginal effect of closing public events is given by $-0.49+0.04 \times D_{i}$, so the predicted marginal effect for a full dictatorship $\left(D_{i}=0\right)$ is a $49 \%$ reduction of deaths, while for a full democracy $\left(D_{i}=10\right)$ it is a $9 \%$ reduction in deaths.

\subsection{Heterogeneous effects of policy responses: Non-linear interaction}

Here, we relax the assumption of linearity between the multiplicative terms $D_{i} * P_{i, t}$, employing a kernel smoothing estimator of the marginal effect (Hainmueller, Mummolo and Xu, 2019). The kernel approach allows us to flexibly estimate the functional form of the marginal effect of $P$ on $Y$ across the values of $D$ by estimating a series of local effects with a kernel re-weighting scheme.

Formally, the kernel smoothing method is based on the following semi-parametric model:

$$
Y=f(D)+g(D) P+\gamma(D) X+\epsilon,
$$

in which $f(),. g($.$) , and \gamma($.$) are smoothing functions of D$, and $g($.$) captures the marginal effect of P$ on $Y$. The kernel regression nests the standard interaction model given in equation 7 as a special case when $f(D)=\beta_{0}+\beta_{1} D, g(D)=\beta_{1}+\beta_{3} D$ and $\gamma(D)=\gamma$. In other words, the kernel approach will converge to a linear function when the assumption of linearity is true. However, multiplicative terms can vary freely across the range of $D$. In addition, if covariates $X$ are included in the model, the coefficients of those covariates are also allowed to vary freely across the range of $D$, resulting in a flexible estimator that helps to guard against mis-specification bias with respect to the covariates.

As all of the significant interaction signs in Table 6 go in the same direction, for simplicity we present the kernel regression result here with the policy stringency index (as was used in Table 5) 


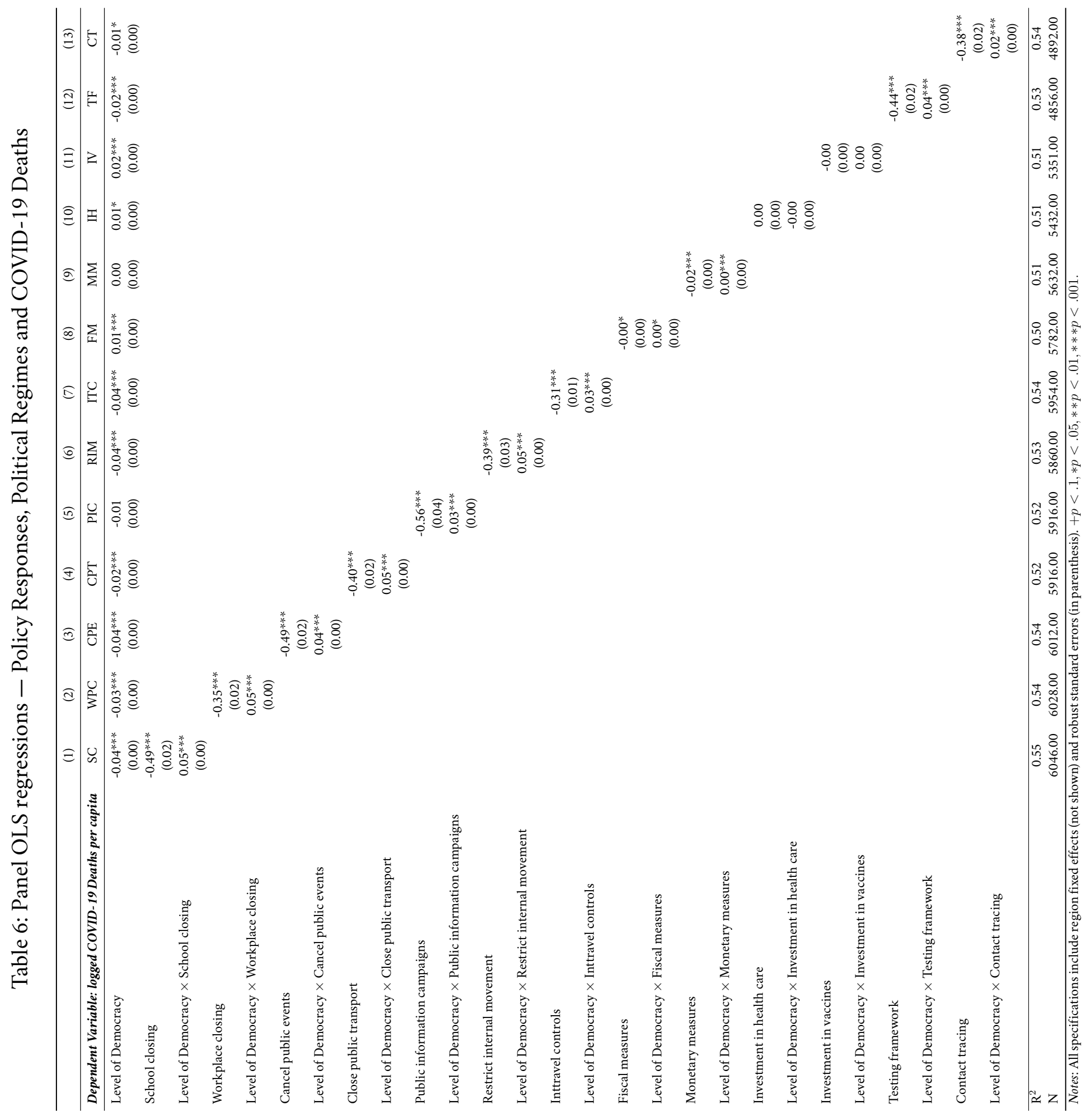




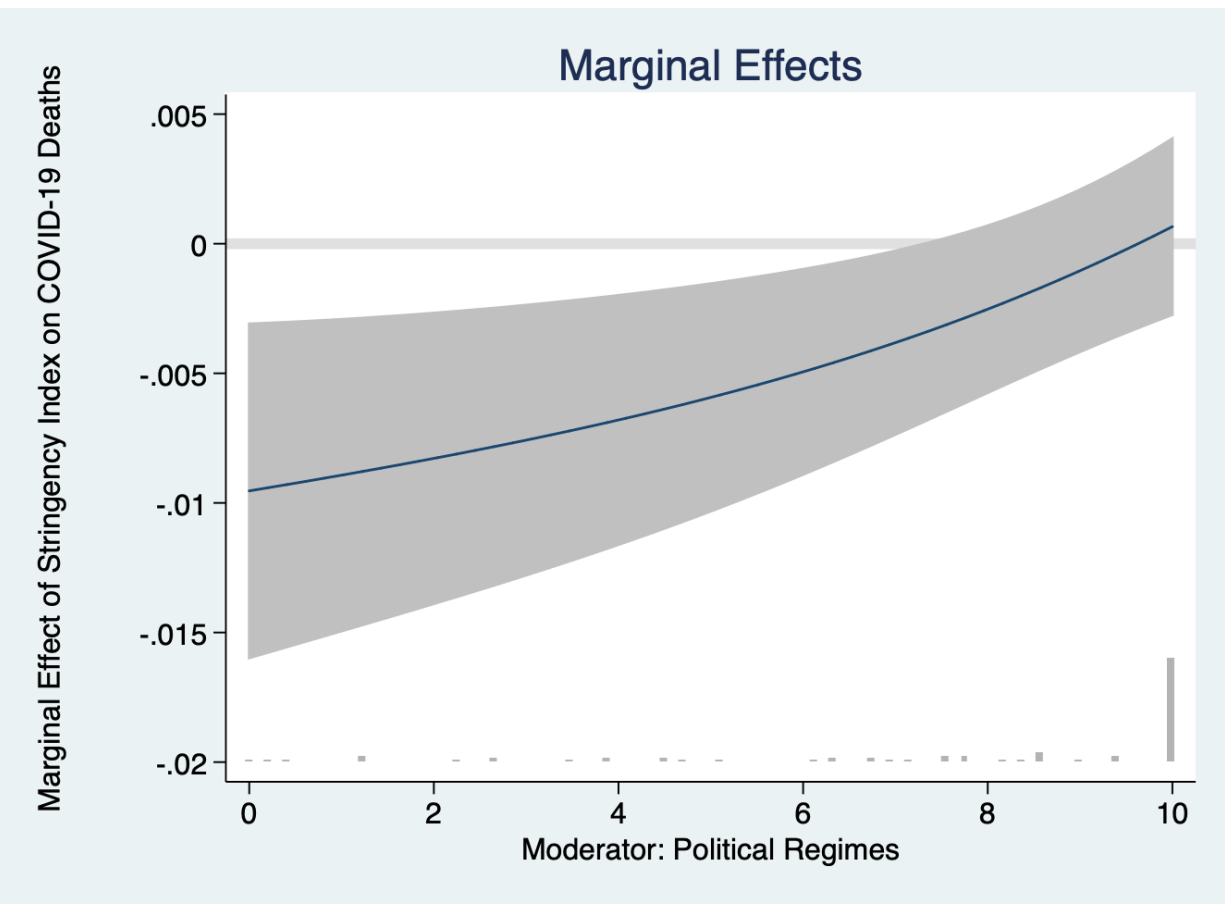

Figure 3: Marginal effect of the stringency index on logged COVID-19 deaths per capita, conditional on political regimes. All models contain Log (Confirmed cases), Percentage of tropical climate in 2012, Population density (people per sq, km of land area), Trade (\% of GDP), SARS, and Log (Airports). All specifications include region and day fixed effects and cluster standard errors at country-level. Grey areas represent 95\% confidence intervals. Histograms in the bottom of the figures presents levels of political regimes.

interacted with the democracy level. We fit a model with regional and day fixed-effects, our standard vector of controls and standard errors clustered at the country-level Figure 3 summarizes the main result graphically, presenting the marginal effect of an increase in the policy stringency index as a function of the level of democracy in the country.

The relationship in Figure 3 is almost linear, although we are estimating a flexible kernel model. Figure 3 shows that the marginal effect of the stringency index - conditional on different levels of political regimes - reduces (logged) COVID-19 deaths per capita. The marginal effect of policy responses on (logged) COVID-19 deaths per capita is negative, conditional on relatively low levels of democracy (below 7.5 points on the FH_iPolity scale). Non-democratic countries that adopt stringent policy measures reduce the number of (logged) COVID-19 deaths per capita, whereas highly democratic countries (above 9 points) adopting the same policy responses do not necessarily, as the confidence interval for 
more democratic countries (above 7.5 points) crosses zero.

\section{Discussion and conclusions}

Our analysis demonstrates that in the early stages of the COVID-19 pandemic, more democratic countries experienced deaths sooner and on a larger scale. For advocates of democratic governance, these results are unsettling. We have several lines of rationalizing the findings, which we believe open up some crucial debates in political science.

There may be systematic under-reporting of COVID-19 deaths in less democratic countries. In some cases, under-reporting could be a political decision. In other cases, it may reflect a lack of state capacity to perform the testing necessary to determine the real cause of death (Economist, 2020). ${ }^{24} \mathrm{We}$ have tried to deal with this through our instrumental variable strategy and by including controls for governmental transparency, testing rates and sub-sample analyses, but it remains a concern.

Centralized decision-making may be advantageous when it comes to responding to pandemics (Schwartz, 2012). Table 5 shows that more democratic countries had imposed less stringent restrictions during the first 100 days of the crisis. With fewer checks built into the policy-making process, public health policy responses can be made more quickly and perhaps more incisively in autocratic governments. Especially for policies that impinge on civil liberties and privacy, autocratic governments have a far freer hand in imposing restrictions on their citizens. The trade-off between the capacity to protect the public health and personal liberties is a central debate during, and probably well after, the COVID-19 crisis (Harari, 2020).

Autocratic governments may have had an extra advantage to the extent that their citizens are more obedient to governmental decrees, especially those that may disrupt the social and business lives of

\footnotetext{
${ }^{24}$ In Table A.10 in the Appendix, we display repeated cross-section OLS regressions always controlling for day and region fixed-effects and also three measures of state capacity - Government Effectiveness, Quality of Government, and State Fragility Index - in columns 2, 3, and 4. We still observe more (logged) deaths per capita in more democratic countries, but these results are smaller than in the specifications from the main paper. Appendix Table A. 11 interacts political regimes and the three measures of state capacity, controlling for time and region fixed-effects. The results for democracy still hold. These results suggest that state capacity can moderate the effect of political regimes on the (logged) number of COVID-19 deaths. To illustrate our point, democratic countries with a lot of state capacity, such as Germany and South Korea, did relatively well in fighting the pandemic in its early stages.
} 
citizens. Figure 3 demonstrates that more stringent policies decreased deaths in less democratic countries, but not necessarily in fully democratic ones. Whether it comes from higher public support for government initiatives (possibly, through the threat of force) or from the government's ability to stifle debate around their decrees in the media, the greater obedience of citizens in autocracies may have had a role in the lower scale of deaths. Protests against social distancing restrictions in democracies with different institutional performances, such as Brazil and the United States, seem to reinforce this point.

Finally, this paper contributes to a substantive topic that will have broad and lasting implications. It may well be many years until we have a clear understanding how the COVID-19 crisis will impact our societies. As the pandemic started in East Asia, the location of some of the best-managed autocracies, it may be that our sample disproportionately includes the autocratic governments with high state capacity. Therefore, it is an area for future research to see if our results hold when autocracies with lower state capacity are eventually included in the sample.

Moreover, the autocratic advantage may be short-term and only observable in terms of the death toll directly due to the pandemic. Looking at other performance indicators that COVID-19 will affect in the long-run, such as mental health and other well-being measures, as well as the economic recovery, may well melt awat the advantage that our estimations have documented in the short term. We believe strongly in the inherent value of the freedom and civil liberties that democracies provide. However, democratic institutions and the citizens living in them must develop emergency strategies to respond quickly and more efficiently to future outbreaks of pandemics, or similar urgent crises. Those strategies may well include expedited decision-making processes that place unpalatable restrictions on individual liberties. In our view, failure to deal effectively with pandemics poses a risk to the public's trust in democratic governance and could contribute to the democratic roll-back that is happening in some regions of the world. Giving up some liberties in the short-run within democratic institutions may be necessary to ensure liberties into the future with democratic institutions. 


\section{References}

Acemoglu, Daron and James A Robinson. 2012. Why Nations Fail: The Origins of Power, Prosperity, and Poverty. New York: Crown Books.

Acemoglu, Daron, Suresh Naidu, Pascual Restrepo and James A Robinson. 2019. “Democracy Does Cause Growth.” Journal of Political Economy 127(1):47-100.

Ackerman, Bruce A. 2006. Before the Next Attack: Preserving Civil Liberties in an Age of Terrorism. New Haven: Yale University Press.

Adolph, Christopher, Kenya Amano, Bree Bang-Jensen, Nancy Fullman and John Wilkerson. 2020. "Pandemic Politics: Timing State-Level Social Distancing Responses to COVID-19." medRxiv .

Allcott, Hunt, Levi Boxell, Jacob Conway, Matthew Gentzkow, Michael Thaler and David Y Yang. 2020. "Polarization and Public Health: Partisan Differences in Social Distancing During COVID19.” Available at SSRN 3570274.

Anderson, Roy M, Hans Heesterbeek, Don Klinkenberg and T Déirdre Hollingsworth. 2020. "How Will Country-Based Mitigation Measures Influence the Course of the COVID-19 Epidemic?" The Lancet 395(10228):931-934.

Barrios, John M and Yael Hochberg. 2020. Risk Perception Through the Lens of Politics in the Time of the COVID-19 Pandemic. Working Paper 27008 National Bureau of Economic Research.

Bellinger, Nisha Mukherjee. 2019. "Why Democracy Matters: Democratic Attributes and Human Well-Being." Journal of International Relations and Development 22(2):413-440.

Bertelsmann Stiftung. 2020. Transformation Index BTI 2020: Governance in International Comparison. Verlag Bertelsmann Stiftung.

Besley, Timothy. 2006. Principled Agents?: The Political Economy of Good Government. Oxford: Oxford University Press. 
Besley, Timothy and Masayuki Kudamatsu. 2006. "Health and Democracy." American Economic Review 96(2):313-318.

Bollyky, Thomas J, Tara Templin, Matthew Cohen, Diana Schoder, Joseph L Dieleman and Simon Wigley. 2019. "The Relationships Between Democratic Experience, Adult Health, and CauseSpecific Mortality in 170 Countries Between 1980 and 2016: An Observational Analysis." The Lancet 393(10181):1628-1640.

Bolt, Jutta, Robert Inklaar, Herman de Jong and Jan Luiten van Zanden. 2018. "Maddison Project Database 2018." Groningen Growth and Development Centre .

Coppedge, Michael, John Gerring, Carl Henrik Knutsen, Staffan I Lindberg, Jan Teorell, David Altman, Michael Bernhard, M Steven Fish, Adam Glynn, Allen Hicken et al. 2020. “V-Dem Codebook V10.”

Coronavirus Resource Center, John Hopkins University. 2020. “COVID-19 Case Tracker.”

Cox, David R. 1972. "Regression Models And Life-Tables." Journal of the Royal Statistical Society: Series B (Methodological) 34(2):187-202.

Cronert, Axel. 2020. “Democracy, State Capacity, and COVID-19 Related School Closures.” APSA Preprint .

Dahl, Robert Alan. 1989. Democracy and its Critics. New Haven: Yale University Press.

Dewey, John. 1923. Democracy and Education: An Introduction to the Philosophy of Education. New York: Macmillan.

Dong, Ensheng, Hongru Du and Lauren Gardner. 2020. "An Interactive Web-Based Dashboard to Track Covid-19 in Real Time.” The Lancet infectious diseases .

Dorsch, Michael T and Paul Maarek. 2019. "Democratization and the Conditional Dynamics of Income Distribution." American Political Science Review 113(2):385-404.

Economist. 2020. “Tracking COVID-19 Excess Deaths Across Countries.” Economist, April 16, 2020. 
Fujiwara, Thomas. 2015. "Voting Technology, Political Responsiveness, and Infant Health: Evidence from Brazil.” Econometrica 83(2):423-464.

Hadenius, Axel and Jan Teorell. 2007. "Pathways from Authoritarianism." Journal of Democracy 18(1):143-157.

Hainmueller, Jens, Jonathan Mummolo and Yiqing Xu. 2019. "How Much Should We Trust Estimates From Multiplicative Interaction Models? Simple Tools to Improve Empirical Practice." Political Analysis 27(2):163-192.

Hale, Thomas, Anna Petherick, Toby Phillips and Samuel Webster. 2020a. "Oxford COVID-19 Government Response Tracker." Blavatnik School of Government .

Hale, Thomas, Anna Petherick, Toby Phillips and Samuel Webster. 2020b. "Variation in Government Responses to COVID-19.” Blavatnik School of Government Working Paper April(7).

Harari, Yuval Noah. 2020. “The World After Coronavirus.” Financial Times, March 20, 2020.

Heymann, David L and Nahoko Shindo. 2020. “COVID-19: What is Next for Public Health?” The Lancet 395(10224):542-545.

Hobbes, Thomas. 1970. “Leviathan (1651).” Glasgow 1974.

Hollyer, James R, B Peter Rosendorff and James Raymond Vreeland. 2014. "Measuring Transparency." Political Analysis 22(4):413-434.

House, Freedom. 2019. "Freedom in the world 2019: Democracy in retreat. Washington DC: Freedom House.”.

Jiang, Fang, Liehua Deng, Liangqing Zhang, Yin Cai, Chi Wai Cheung and Zhengyuan Xia. 2020. "Review of the Clinical Characteristics of Coronavirus Disease 2019 (COVID-19)." Journal of General Internal Medicine pp. 1-5. 
Joe Hasell, Esteban Ortiz-Ospina, Edouard Mathieu Hannah Ritchie Diana Beltekian Bobbie Macdonald and Max Roser. 2020. "Our World in Data COVID-19 Testing Dataset." Our World in Data .

Justesen, Mogens K. 2012. “Democracy, Dictatorship, and Disease: Political Regimes and HIV/AIDS.” European Journal of Political Economy 28(3):373-389.

Kaplan, Edward L and Paul Meier. 1958. “Nonparametric Estimation From Incomplete Observations.” Journal of the American Statistical Association 53(282):457-481.

Kaufmann, Daniel, Aart Kraay and Massimo Mastruzzi. 2011. "The Worldwide Governance Indicators: Methodology and Analytical Issues." Hague Journal on the Rule of Law 3(2):220-246.

Kavanagh, Matthew M. 2020. “Authoritarianism, Outbreaks, and Information Politics." The Lancet Public Health 5(3):e135-e136.

Malesky, Edmund and Jonathan London. 2014. “The Political Economy of Development in China and Vietnam." Annual Review of Political Science 17:395-419.

Marshall, M. G., K. Jaggers and T. R. Gurr. 2019. Polity IV Project, Political Regime Characteristics and Transitions, 1800-2017. Center for Systemic Peace.

Marshall, Monty G, Ted Robert Gurr and Keith Jaggers. 2017. "Global Report 2017: Conflict, Governance, and State Fragility." Center for Systemic Peace .

Mill, John Stuart. 1887. On liberty. London, UK: Longmans, Green.

Nunn, Nathan and Diego Puga. 2012. "Ruggedness: The Blessing of Bad Geography in Africa." Review of Economics and Statistics 94(1):20-36.

Patterson, Andrew C and Gerry Veenstra. 2016. "Politics and Population Health: Testing the Impact of Electoral Democracy." Health er Place 40:66-75. 
Pemstein, Daniel, Kyle L Marquardt, Eitan Tzelgov, Yi-ting Wang, Joshua Krusell and Farhad Miri. 2018. “The V-Dem measurement model: Latent Variable Analysis for Cross-National and CrossTemporal Expert-Coded Data." V-Dem Working Paper 21.

PRS, Group. 2019. “International Country Risk Guide, Political Risk Services.”.

Przeworski, Adam and Fernando Limongi. 1993. "Political Regimes and Economic Growth." Journal of Economic Perspectives 7(3):51-69.

Ross, Michael. 2006. "Is Democracy Good for the Poor?” American Journal of Political Science 50(4):860874.

Schmitt, Carl. 2005. Political Theology: Four Chapters on the Concept of Sovereignty. Chicago: University of Chicago Press.

Schwartz, Jonathan. 2012. “Compensating for the 'Authoritarian Advantage' in Crisis Response: A Comparative Case Study of SARS Pandemic Responses in China and Taiwan." Journal of Chinese Political Science 17(3):313-331.

Singer, Natasha and Choe Sang-Hun. 2020. "As Coronavirus Surveillance Escalates, Personal Privacy Plummets." The New York Times, March 23.

Sohrabi, Catrin, Zaid Alsafi, Niamh O’Neill, Mehdi Khan, Ahmed Kerwan, Ahmed Al-Jabir, Christos Iosifidis and Riaz Agha. 2020. "World Health Organization Declares Global Emergency: A Review of the 2019 Novel Coronavirus (COVID-19).” International Journal of Surgery .

Teorell, Jan, Stefan Dahlberg, Sören Holmberg, Bo Rothstein, Natalia Alvarado Pachon and Sofia Axelsson. 2020. The Quality of Government Standard Dataset, version Jan20. University of Gothenburg. The Quality of Government Institute.

The World Factbook, CIA. 2020. "Total Number of Airports by Country.”

Truex, Rory. 2017. "The Myth of the Democratic Advantage." Studies in Comparative International Development 52(3):261-277. 
van der Windt, Peter and Sotiris Vandoros. 2017. “Democracy and Health: Evidence from WithinCountry Heterogeneity in the Congo." Social Science er Medicine 194:10-16.

Weeks, Jessica L. 2008. “Autocratic Audience Costs: Regime Type and Signaling Resolve.” International Organization 62(1):35-64.

Welander, Anna, Carl Hampus Lyttkens and Therese Nilsson. 2015. “Globalization, Democracy, and Child Health in Developing Countries." Social Science er Medicine 136:52-63.

WHO. 2003. "Summary Table of SARS Cases by Country, 1 November 2002-7 August 2003.” Weekly Epidemiological Record 78(35):310-311.

WHO. 2020a. "Coronavirus disease 2019 (COVID-19): situation report, 72.”.

WHO. 2020b. "WHO Timeline - COVID-19.".

Wigley, Simon and Arzu Akkoyunlu-Wigley. 2017. "The Impact of Democracy and Media Freedom on Under-5 Mortality, 1961-2011.” Social Science er Medicine 190:237-246.

Williams, Andrew. 2015. "A Global Index of Information Transparency and Accountability." Journal of Comparative Economics 43(3):804-824.

Wittman, Donald. 1989. "Why Democracies Produce Efficient Results." Journal of Political Economy 97(6):1395-1424.

Wooldridge, Jeffrey M. 2002. "Econometric Analysis of Cross Section and Panel Data. MIT Press, Cambridge, MA.."

World Bank. 2016. "World Development Indicators (WDI).” The World Bank, Washington DC . 


\title{
A Online Appendix - Not for Print Publication
}

\author{
Table A.1: Summary statistics - Cross-Section Data
}

\begin{tabular}{lccccc}
\hline \hline \multicolumn{1}{c}{ Variable } & Obs & Mean & Std. Dev. & Min & Max \\
\hline Level of Democracy (Freedom House/Imputed Polity) & 117 & 6.71 & 3.12 & 0 & 10 \\
Level of Democracy (binary indicator) & 121 & .73 & .45 & 0 & 1 \\
Political corruption index & 115 & .47 & .3 & .01 & .95 \\
Performance of Democratic Institutions & 88 & 4.81 & 2.61 & 1 & 10 \\
\hline Confirmed Cases & 119 & 12234.22 & 45824.69 & 2 & 432132 \\
Confirmed Deaths & 119 & 734.03 & 2750.72 & 0 & 17669 \\
Policy Stringency Index & 119 & 80.57 & 17.03 & 11.9 & 100 \\
Tests per 1000 & 59 & 8.28 & 14.87 & .03 & 99.3 \\
Real GDP per Capita & 112 & 21957.04 & 21510.39 & 692 & 139783 \\
Percentage tropical climate in 2012 & 115 & 34.7 & 42.45 & 0 & 100 \\
Population (in millions) & 112 & 61.14 & 184.77 & .09 & 1403.5 \\
Population ages 65 and above (\% of total population) & 116 & 9.16 & 6.42 & .99 & 26.59 \\
Population density (people per sq. km of land area) & 115 & 223.72 & 760.62 & 1.97 & 7908.72 \\
Trade (\% of GDP) & 114 & 81.44 & 54.84 & 20.72 & 413.52 \\
SARS & 117 & .03 & .18 & 0 & 1 \\
Airports & 118 & 334.52 & 1308.17 & 1 & 13513 \\
Economic data transparency index & 125 & .9439515 & 1.988632 & -6.675819 & 5.635727 \\
Information and accountability transparency index & 163 & 55.02 & 13.78 & 21 & 80 \\
\hline
\end{tabular}


Figure A.1: Geographic Variation in Incidence of COVID-19 and Policy Responses
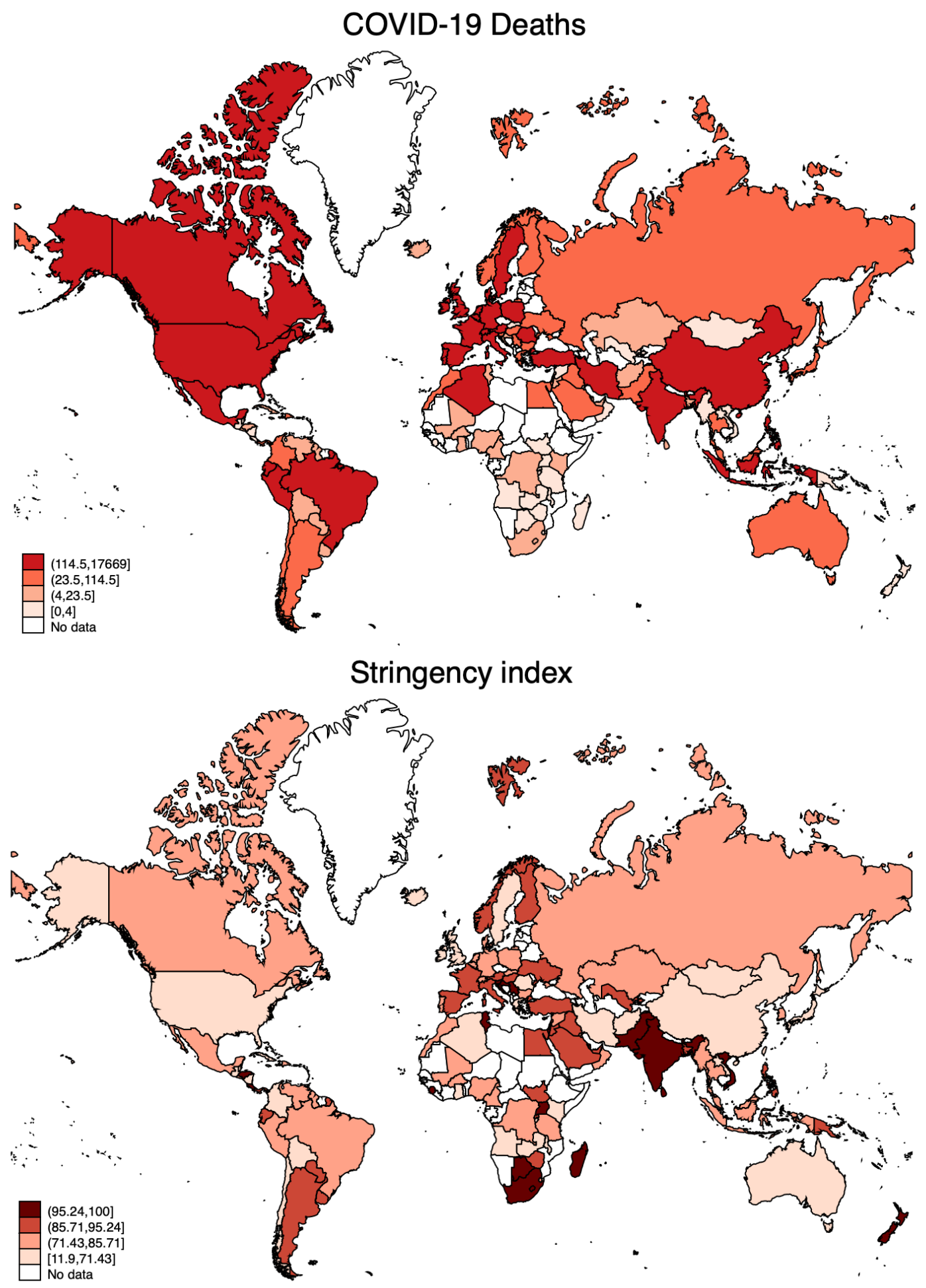
Table A.2: Summary statistics - Panel Data

\begin{tabular}{lccccc}
\hline \hline \multicolumn{1}{c}{ Variable } & Obs & Mean & Std. Dev. & Min & Max \\
\hline Level of Democracy (Freedom House/Imputed Polity) & 11721 & 6.75 & 3.1 & 0 & 10 \\
Level of Democracy (binary indicator) & 12120 & .73 & .44 & 0 & 1 \\
Political corruption index & 11521 & .47 & .3 & .01 & .95 \\
Performance of Democratic Institutions & 8821 & 4.86 & 2.62 & 1 & 10 \\
\hline Confirmed Cases & 6935 & 2886.11 & 16703.68 & 0 & 432132 \\
Confirmed Deaths & 6935 & 138.88 & 966.99 & 0 & 17669 \\
Real GDP per Capita & 11221 & 22062.18 & 21331.29 & 692 & 139783 \\
Percentage tropical climate in 2012 & 11521 & 34.42 & 42.3 & 0 & 100 \\
Population (in millions) & 11221 & 60.96 & 183.81 & .09 & 1403.5 \\
Population ages 65 and above (\% of total population) & 11621 & 9.28 & 6.42 & .99 & 26.59 \\
Population density (people per sq. km of land area) & 11521 & 224.15 & 756.56 & 1.97 & 7908.72 \\
Trade (\% of GDP) & 11421 & 82.21 & 54.88 & 20.72 & 413.52 \\
SARS & 11721 & .03 & .18 & 0 & 1 \\
Airports & 11920 & 331.62 & 1296.42 & 1 & 13513 \\
Information and accountability transparency index & 11151 & 57.42 & 13.17 & 21 & 80 \\
Government Effectiveness, Estimate & 11700 & .18 & .98 & -2.35 & 2.21 \\
ICRG Indicator of Quality of Government & 10500 & .57 & .21 & .14 & .97 \\
State Fragility Index & 11200 & 6.94 & 6.02 & 0 & 24 \\
\hline Stringency Index & 11343 & 25.69 & 32.23 & 0 & 100 \\
School closing & 11587 & .53 & .87 & 0 & 2 \\
Workplace closing & 11426 & .39 & .76 & 0 & 2 \\
Cancel public events & 11565 & .56 & .88 & 0 & 2 \\
Close public transport & 11336 & .23 & .6 & 0 & 2 \\
Public information campaigns & 11341 & .5 & .5 & 0 & 1 \\
Restrict internal movement & 11208 & .4 & .77 & 0 & 2 \\
Int travel controls & 11296 & 1.14 & 1.32 & 0 & 3 \\
Fiscal measures & 10829 & $7.42 \mathrm{e}+09$ & $1.51 \mathrm{e}+11$ & 0 & $3.33 \mathrm{e}+12$ \\
Monetary measures & 10669 & 7.37 & 197.06 & -.75 & 11750 \\
Investment in health care & 10384 & $2.78 \mathrm{e}+07$ & $1.61 \mathrm{e}+09$ & 0 & $1.50 \mathrm{e}+11$ \\
Investment in vaccines & 10168 & 265007.5 & 9814192 & 0 & $8.26 \mathrm{e}+08$ \\
Testing framework & 9908 & .61 & .76 & 0 & 3 \\
Contact tracing & 9838 & .55 & .78 & 0 & 2 \\
\hline & & & & & \\
\hline
\end{tabular}

Figure A.2: Histograms of COVID-19 Deaths per capita and Logged COVID-19 Deaths per capita
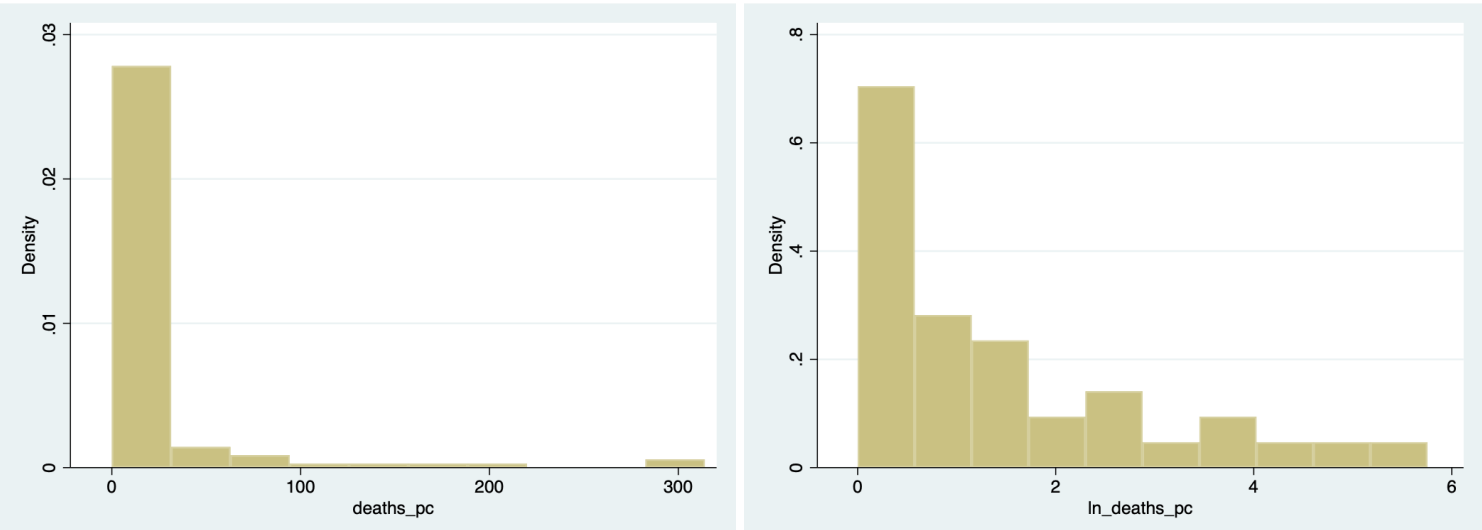


\begin{tabular}{|c|c|c|c|c|}
\hline Countries & Deaths & Deaths per capita & Deaths per 10,000 & Deaths rate \\
\hline Italy & 17669 & 297.3081 & 1.7669 & .1267304 \\
\hline United States & 14817 & 45.98988 & 1.4817 & .0342881 \\
\hline Spain & 14555 & 314.0402 & 1.4555 & .0992229 \\
\hline France & 10869 & 162.3501 & 1.0869 & .1324712 \\
\hline United Kingdom & 7097 & 107.8759 & .7097 & .1168557 \\
\hline Iran & 3993 & 49.74001 & .3993 & .0618245 \\
\hline China & 3339 & 2.379052 & .3339 & .040292 \\
\hline Netherlands & 2248 & 132.3339 & .2248 & 1093971 \\
\hline Belgium & 2240 & 197.2112 & .224 & .0957142 \\
\hline Germany & 2107 & 25.72189 & .2107 & .0194728 \\
\hline Turkey & 812 & 10.21224 & .0812 & .0212421 \\
\hline Brazil & 800 & 3.852584 & .08 & .0502292 \\
\hline Switzerland & 705 & 83.9112 & .0705 & .0310436 \\
\hline Sweden & 687 & 69.83458 & .0687 & .0816011 \\
\hline Canada & 435 & 11.98683 & .0435 & .0225693 \\
\hline Portugal & 380 & 36.63842 & .038 & .0289171 \\
\hline Austria & 273 & 31.33559 & .0273 & .0210502 \\
\hline Ecuador & 242 & 14.76954 & .0242 & .054382 \\
\hline Indonesia & 240 & .9191337 & .024 & .0811908 \\
\hline Ireland & 235 & 49.72411 & .0235 & .0377571 \\
\hline Denmark & 218 & 38.16613 & .0218 & .0403554 \\
\hline Romania & 209 & 10.56725 & .0209 & .0438983 \\
\hline Algeria & 205 & 5.048509 & .0205 & .1304071 \\
\hline South Korea & 204 & 4.016387 & .0204 & .0195721 \\
\hline Philippines & 182 & 1.761514 & .0182 & .0470284 \\
\hline Mexico & 174 & 1.364273 & .0174 & .0546998 \\
\hline India & 166 & .1253614 & .0166 & .0289501 \\
\hline Poland & 159 & 4.159646 & .0159 & .0305475 \\
\hline Peru & 121 & 3.808164 & .0121 & .0278673 \\
\hline Dominican Republic & 108 & 10.142 & .0108 & .0511606 \\
\hline Egypt & 103 & 1.076407 & .0103 & .0660256 \\
\hline Morocco & 93 & 2.636295 & .0093 & .0729412 \\
\hline Greece & 83 & 7.421505 & .0083 & .0440552 \\
\hline Japan & 81 & .6340582 & .0081 & .0190275 \\
\hline Norway & 80 & 15.22448 & .008 & .0133111 \\
\hline Israel & 71 & 8.667174 & .0071 & .00755 \\
\hline Iraq & 69 & 1.85471 & .0069 & .0574043 \\
\hline Hungary & 66 & 6.766954 & .0066 & .0673469 \\
\hline Malaysia & 65 & 2.084184 & .0065 & .0157805 \\
\hline Argentina & 65 & 1.482413 & .0065 & .0362117 \\
\hline Serbia & 65 & 9.208987 & .0065 & .0243811 \\
\hline Panama & 63 & 15.61679 & .0063 & .0249209 \\
\hline Russia & 63 & .4376079 & .0063 & .0072648 \\
\hline Pakistan & 63 & .3260811 & .0063 & .0145766 \\
\hline Colombia & 55 & 1.130445 & .0055 & .026777 \\
\hline Ukraine & 52 & 1.170153 & .0052 & .0311751 \\
\hline Australia & 50 & 2.072466 & .005 & .0082617 \\
\hline Chile & 48 & 2.680104 & .0048 & .0086549 \\
\hline Luxembourg & 46 & 79.8962 & .0046 & .0151615 \\
\hline Saudi Arabia & 41 & 1.270306 & .0041 & .0139836 \\
\hline
\end{tabular}

Table A.3: The first 50 countries ranked by the number of COVID-19 deaths. The table also shows deaths per capita (in millions), deaths per 10,000 inhabitants, and deaths rate (or deaths per cases). 
Table A.4: Cross-section OLS regressions - alternative samples

\begin{tabular}{|c|c|c|c|c|c|c|}
\hline & \multicolumn{2}{|c|}{ DIAT transparency index } & \multicolumn{2}{|c|}{ HRV transparency index } & \multicolumn{2}{|c|}{ Tests per 1000} \\
\hline & $\begin{array}{l}\text { dropping } \\
\text { 1st decile } \\
\text { (1) }\end{array}$ & $\begin{array}{c}\text { dropping } \\
\text { 1st/10th dcls. } \\
\text { (2) }\end{array}$ & $\begin{array}{c}\text { dropping } \\
11 \text { st decile } \\
\text { (3) }\end{array}$ & $\begin{array}{c}\text { dropping } \\
\text { 1st/10th dcls. } \\
\text { (4) }\end{array}$ & $\begin{array}{c}\text { dropping } \\
\text { 1st decile } \\
\text { (5) }\end{array}$ & $\begin{array}{c}\text { dropping } \\
\text { 1st/10th dcls. } \\
\text { (6) }\end{array}$ \\
\hline \multicolumn{7}{|c|}{ Dependent Variable: logged COVID-19 Deaths per capita } \\
\hline Level of Democracy & $\begin{array}{c}0.17^{* * *} \\
(0.03)\end{array}$ & $\begin{array}{c}0.14^{* * *} \\
(0.03)\end{array}$ & $\begin{array}{c}0.13^{* * * *} \\
(0.03)\end{array}$ & $\begin{array}{l}0.11^{* *} \\
(0.03)\end{array}$ & $\begin{array}{l}0.19^{*} \\
(0.08)\end{array}$ & $\begin{array}{l}0.24^{* *} \\
(0.08)\end{array}$ \\
\hline Log (Confirmed cases) & $\begin{array}{c}0.54^{* * *} \\
(0.07)\end{array}$ & $\begin{array}{c}0.46^{* * *} \\
(0.06)\end{array}$ & $\begin{array}{c}0.52^{* * *} \\
(0.07)\end{array}$ & $\begin{array}{c}0.52^{* * *} \\
(0.07)\end{array}$ & $\begin{array}{c}0.75^{* * * *} \\
(0.12)\end{array}$ & $\begin{array}{c}0.83^{* * *} \\
(0.14)\end{array}$ \\
\hline Log (Real GDP per capita) & $\begin{array}{c}0.02 \\
(0.13)\end{array}$ & $\begin{array}{c}0.10 \\
(0.11)\end{array}$ & $\begin{array}{c}0.01 \\
(0.17)\end{array}$ & $\begin{array}{c}0.01 \\
(0.12)\end{array}$ & $\begin{array}{c}0.14 \\
(0.35)\end{array}$ & $\begin{array}{l}-0.16 \\
(0.45)\end{array}$ \\
\hline Percentage tropical climate in 2012 & $\begin{array}{l}-0.00 \\
(0.00)\end{array}$ & $\begin{array}{c}0.00 \\
(0.00)\end{array}$ & $\begin{array}{l}-0.00 \\
(0.00)\end{array}$ & $\begin{array}{l}-0.00 \\
(0.00)\end{array}$ & $\begin{array}{c}0.01 \\
(0.00)\end{array}$ & $\begin{array}{c}0.01 \\
(0.01)\end{array}$ \\
\hline Population density & $\begin{array}{l}-0.00^{*} \\
(0.00)\end{array}$ & $\begin{array}{l}-0.00^{*} \\
(0.00)\end{array}$ & $\begin{array}{c}-0.00^{* *} \\
(0.00)\end{array}$ & $\begin{array}{c}-0.00^{* *} \\
(0.00)\end{array}$ & $\begin{array}{c}0.00 \\
(0.00)\end{array}$ & $\begin{array}{c}0.00 \\
(0.00)\end{array}$ \\
\hline Trade (\% of GDP) & $\begin{array}{l}0.00^{*} \\
(0.00)\end{array}$ & $\begin{array}{l}0.00^{*} \\
(0.00)\end{array}$ & $\begin{array}{l}0.01^{* *} \\
(0.00)\end{array}$ & $\begin{array}{c}0.01^{* * *} \\
(0.00)\end{array}$ & $\begin{array}{l}0.01+ \\
(0.00)\end{array}$ & $\begin{array}{l}0.01+ \\
(0.01)\end{array}$ \\
\hline SARS & $\begin{array}{c}0.02 \\
(0.35)\end{array}$ & $\begin{array}{c}0.30 \\
(0.41)\end{array}$ & $\begin{array}{l}-0.10 \\
(0.41)\end{array}$ & $\begin{array}{c}0.12 \\
(0.37)\end{array}$ & $\begin{array}{c}0.21 \\
(0.27)\end{array}$ & $\begin{array}{c}0.13 \\
(0.33)\end{array}$ \\
\hline Log (airports) & $\begin{array}{c}-0.26^{* * *} \\
(0.07)\end{array}$ & $\begin{array}{c}-0.24^{* *} \\
(0.07)\end{array}$ & $\begin{array}{l}-0.18^{*} \\
(0.08)\end{array}$ & $\begin{array}{c}-0.12+ \\
(0.07)\end{array}$ & $\begin{array}{l}-0.20 \\
(0.12)\end{array}$ & $\begin{array}{l}-0.18 \\
(0.15)\end{array}$ \\
\hline Days since first case & $\begin{array}{c}-0.01^{*} \\
(0.01)\end{array}$ & $\begin{array}{c}-0.02^{* * *} \\
(0.01)\end{array}$ & $\begin{array}{c}-0.01^{*} \\
(0.01)\end{array}$ & $\begin{array}{c}-0.02^{* * * *} \\
(0.01)\end{array}$ & $\begin{array}{l}-0.02^{*} \\
(0.01)\end{array}$ & $\begin{array}{c}-0.02+ \\
(0.01)\end{array}$ \\
\hline $\mathrm{R}^{2}$ & 0.7393 & 0.6862 & 0.7262 & 0.7150 & 0.7522 & 0.7595 \\
\hline $\mathrm{N}$ & 92 & 76 & 81 & 72 & 44 & 40 \\
\hline
\end{tabular}


Countries coefficients
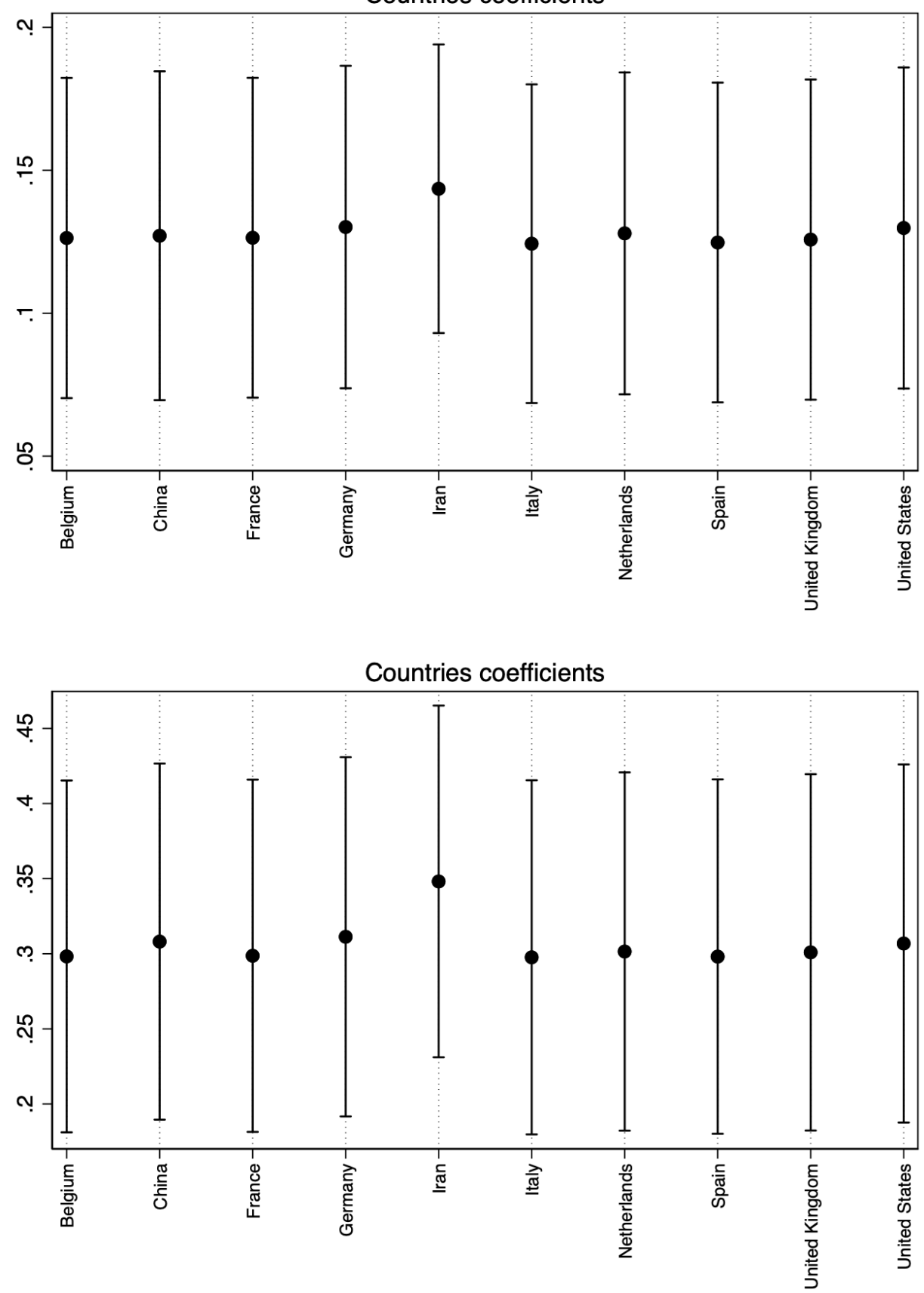

Figure A.3: Leave-One-Out Checks for the OLS and the 2SLS models. The top panel presents the analysis for OLS model. 2SLS model is on the bottom panel. Each estimate is based on a sample that omits the country on the x-axis. Dots are coefficients; bars are 95\% CIs. The dependent variable is logged per capita COVID-19 deaths over time. All models include the following independent variables: Log (Confirmed cases), Log (Real GDP per capita), Percentage of tropical climate in 2012, Population density, Trade, SARS, Log (Airports) and the number of days since the first confirmed case. All specifications include robust standard errors. 


\section{Table A.5: Cross-section Two-Stage Least Squares - First-stage regressions}

\begin{tabular}{|c|c|c|c|c|}
\hline & (1) & (2) & (3) & (4) \\
\hline & $\begin{array}{c}\text { democracy level } \\
\text { FH_iPolity }\end{array}$ & $\begin{array}{c}\text { democracy (binary) } \\
\text { FH_iPolity }\end{array}$ & $\begin{array}{c}\text { political corruption } \\
\text { V-DEM }\end{array}$ & $\begin{array}{c}\text { dem. performance } \\
\text { BTI }\end{array}$ \\
\hline Neighborhood Z (FH_iPolity) & $\begin{array}{c}0.83^{* * *} \\
(0.13)\end{array}$ & $\begin{array}{c}0.10^{* * * *} \\
(0.02)\end{array}$ & & \\
\hline Neighborhood Z (V-DEM) & & & $\begin{array}{l}0.57^{* * *} \\
(0.12)\end{array}$ & \\
\hline Neighborhood Z (BTI) & & & & $\begin{array}{l}0.70^{* *} \\
(0.24)\end{array}$ \\
\hline Log (Confirmed cases) & $\begin{array}{c}0.14 \\
(0.16)\end{array}$ & $\begin{array}{c}0.00 \\
(0.03)\end{array}$ & $\begin{array}{c}0.01 \\
(0.02)\end{array}$ & $\begin{array}{c}0.27 \\
(0.21)\end{array}$ \\
\hline Log (Real GDP per capita) & $\begin{array}{c}0.24 \\
(0.37)\end{array}$ & $\begin{array}{l}-0.02 \\
(0.06)\end{array}$ & $\begin{array}{c}-0.10^{* *} \\
(0.03)\end{array}$ & $\begin{array}{c}0.13 \\
(0.41)\end{array}$ \\
\hline Percentage tropical climate in 2012 & $\begin{array}{l}0.00 \\
(0.01)\end{array}$ & $\begin{array}{l}0.00 \\
(0.00)\end{array}$ & $\begin{array}{l}0.00 \\
(0.00)\end{array}$ & $\begin{array}{l}0.00 \\
(0.01)\end{array}$ \\
\hline Population density & $\begin{array}{c}0.00 \\
(0.00)\end{array}$ & $\begin{array}{c}0.00 \\
(0.00)\end{array}$ & $\begin{array}{l}-0.00 \\
(0.00)\end{array}$ & $\begin{array}{l}0.00 \\
(0.00)\end{array}$ \\
\hline Trade (\% of GDP) & $\begin{array}{l}0.00 \\
(0.01)\end{array}$ & $\begin{array}{c}0.00 \\
(0.00)\end{array}$ & $\begin{array}{l}-0.00 \\
(0.00)\end{array}$ & $\begin{array}{c}0.01 \\
(0.01)\end{array}$ \\
\hline SARS & $\begin{array}{l}-3.53 \\
(2.91)\end{array}$ & $\begin{array}{l}-0.55 \\
(0.35)\end{array}$ & $\begin{array}{l}-0.01 \\
(0.11)\end{array}$ & $\begin{array}{l}-3.99^{*} \\
(1.95)\end{array}$ \\
\hline $\log$ (airports) & $\begin{array}{l}0.10 \\
(0.20)\end{array}$ & $\begin{array}{l}0.03 \\
(0.03)\end{array}$ & $\begin{array}{c}0.00 \\
(0.02)\end{array}$ & $\begin{array}{l}0.10 \\
(0.24)\end{array}$ \\
\hline Days since first case & $\begin{array}{l}-0.02 \\
(0.02)\end{array}$ & $\begin{array}{l}-0.00 \\
(0.00)\end{array}$ & $\begin{array}{l}-0.00 \\
(0.00)\end{array}$ & $\begin{array}{l}-0.03 \\
(0.03)\end{array}$ \\
\hline $\mathrm{R}^{2}$ & 0.4490 & 0.2834 & 0.5736 & 0.2862 \\
\hline First-stage C-D F-stat & 46.688 & 24.291 & 19.976 & 10.703 \\
\hline First-stage K-P F-stat & 41.155 & 24.078 & 24.205 & 8.886 \\
\hline $\mathrm{N}$ & 104 & 104 & 104 & 78 \\
\hline
\end{tabular}


Table A.6: Cross-section Two-Stage Least Squares - Reduced-form regressions

\begin{tabular}{|c|c|c|c|}
\hline & $(1)$ & (2) & (3) \\
\hline \multicolumn{4}{|c|}{ Dependent variable: logged COVID-19 Deaths per capita } \\
\hline Neighborhood Z (FH_iPolity) & $\begin{array}{c}0.25^{\text {*** }} \\
(0.04)\end{array}$ & & \\
\hline Neighborhood Z (V-DEM) & & $\begin{array}{c}-3.46^{* * * *} \\
(0.54)\end{array}$ & \\
\hline Neighborhood Z (BTI) & & & $\begin{array}{c}0.02 \\
(0.07)\end{array}$ \\
\hline Log (Confirmed cases) & $\begin{array}{c}0.52^{* * * *} \\
(0.06)\end{array}$ & $\begin{array}{c}0.48^{* * * *} \\
(0.06)\end{array}$ & $\begin{array}{c}0.38^{* * *} \\
(0.06)\end{array}$ \\
\hline Log (Real GDP per capita) & $\begin{array}{l}-0.00 \\
(0.10)\end{array}$ & $\begin{array}{l}-0.10 \\
(0.09)\end{array}$ & $\begin{array}{c}0.08 \\
(0.09)\end{array}$ \\
\hline Percentage tropical climate in 2012 & $\begin{array}{l}-0.00 \\
(0.00)\end{array}$ & $\begin{array}{c}0.00 \\
(0.00)\end{array}$ & $\begin{array}{c}0.00 \\
(0.00)\end{array}$ \\
\hline Population density & $\begin{array}{l}-0.00 \\
(0.00)\end{array}$ & $\begin{array}{l}-0.00 \\
(0.00)\end{array}$ & $\begin{array}{l}-0.00 \\
(0.00)\end{array}$ \\
\hline Trade (\% of GDP) & $\begin{array}{l}0.00^{*} \\
(0.00)\end{array}$ & $\begin{array}{l}0.00^{*} \\
(0.00)\end{array}$ & $\begin{array}{c}0.00 \\
(0.00)\end{array}$ \\
\hline SARS & $\begin{array}{l}-0.89 \\
(0.71)\end{array}$ & $\begin{array}{c}-0.76+ \\
(0.39)\end{array}$ & $\begin{array}{c}0.05 \\
(0.35)\end{array}$ \\
\hline Log (airports) & $\begin{array}{c}-0.24^{* * *} \\
(0.06)\end{array}$ & $\begin{array}{l}-0.14^{*} \\
(0.05)\end{array}$ & $\begin{array}{c}-0.11+ \\
(0.06)\end{array}$ \\
\hline Days since first case & $\begin{array}{c}-0.02^{* *} \\
(0.01)\end{array}$ & $\begin{array}{c}-0.02^{* * *} \\
(0.01)\end{array}$ & $\begin{array}{c}-0.02^{* * *} \\
(0.01)\end{array}$ \\
\hline $\mathrm{R}^{2}$ & 0.7539 & 0.7948 & 0.5506 \\
\hline $\mathrm{N}$ & 104 & 104 & 78 \\
\hline
\end{tabular}

Notes: All specifications include robust standard errors (in parenthesis).

$+p<.1, * p<.05, * * p<.01, * * * p<.001$. 
Table A.7: Cross-section regressions - alternative death measures

\begin{tabular}{|c|c|c|c|c|c|c|}
\hline \multirow[t]{3}{*}{ Panel A } & \multicolumn{6}{|c|}{ Ordinary Least Squares } \\
\hline & (1) & (2) & (3) & (4) & (5) & (6) \\
\hline & $\begin{array}{l}\text { Log (deaths p.c.) } \\
\text { weighted by }+65\end{array}$ & Log (deaths) & deaths p.c. & $\begin{array}{c}\text { deaths p.c. } \\
\text { weighted by }+65\end{array}$ & death rate & $\log$ (death rate) \\
\hline Level of Democracy & $\begin{array}{l}0.292^{* * *} \\
(0.04)\end{array}$ & $\begin{array}{c}0.087^{* *} \\
(0.03)\end{array}$ & $\begin{array}{c}3.288^{* *} \\
(1.19)\end{array}$ & $\begin{array}{c}71.496^{* *} \\
(24.87)\end{array}$ & $\begin{array}{c}0.002+ \\
(0.00)\end{array}$ & $\begin{array}{c}0.049^{*} \\
(0.02)\end{array}$ \\
\hline Log (Confirmed cases) & $\begin{array}{l}0.765^{* * *} \\
(0.08)\end{array}$ & $\begin{array}{l}1.002^{* * *} \\
(0.08)\end{array}$ & $\begin{array}{c}13.072^{* *} \\
(4.05)\end{array}$ & $\begin{array}{c}231.660^{* *} \\
(83.32)\end{array}$ & $\begin{array}{l}0.001 \\
(0.00)\end{array}$ & $\begin{array}{l}0.094 \\
(0.06)\end{array}$ \\
\hline Log (Real GDP per capita) & $\begin{array}{l}0.175 \\
(0.19)\end{array}$ & $\begin{array}{c}-0.458^{* *} \\
(0.14)\end{array}$ & $\begin{array}{c}-9.523+ \\
(4.84)\end{array}$ & $\begin{array}{c}-180.884+ \\
(97.18)\end{array}$ & $\begin{array}{c}-0.014^{*} \\
(0.01)\end{array}$ & $\begin{array}{c}-0.268^{*} \\
(0.11)\end{array}$ \\
\hline Percentage tropical climate in 2012 & $\begin{array}{c}-0.002 \\
(0.00)\end{array}$ & $\begin{array}{c}-0.001 \\
(0.00)\end{array}$ & $\begin{array}{l}-0.079 \\
(0.07)\end{array}$ & $\begin{array}{r}-1.827 \\
(1.45)\end{array}$ & $\begin{array}{c}-0.000 \\
(0.00)\end{array}$ & $\begin{array}{c}-0.002 \\
(0.00)\end{array}$ \\
\hline Population density & $\begin{array}{c}-0.000+ \\
(0.00)\end{array}$ & $\begin{array}{c}-0.000 \\
(0.00)\end{array}$ & $\begin{array}{l}0.000 \\
(0.00)\end{array}$ & $\begin{array}{l}0.024 \\
(0.06)\end{array}$ & $\begin{array}{l}0.000 \\
(0.00)\end{array}$ & $\begin{array}{l}0.000 \\
(0.00)\end{array}$ \\
\hline Trade (\% of GDP) & $\begin{array}{c}0.005+ \\
(0.00)\end{array}$ & $\begin{array}{l}0.001 \\
(0.00)\end{array}$ & $\begin{array}{l}0.104 \\
(0.07)\end{array}$ & $\begin{array}{l}1.116 \\
(1.48)\end{array}$ & $\begin{array}{l}0.000 \\
(0.00)\end{array}$ & $\begin{array}{l}0.001 \\
(0.00)\end{array}$ \\
\hline SARS & $\begin{array}{l}0.418 \\
(0.41)\end{array}$ & $\begin{array}{l}0.158 \\
(0.47)\end{array}$ & $\begin{array}{c}-38.977^{*} \\
(16.00)\end{array}$ & $\begin{array}{c}-760.819^{*} \\
(321.40)\end{array}$ & $\begin{array}{c}-0.021 \\
(0.02)\end{array}$ & $\begin{array}{c}-0.262 \\
(0.32)\end{array}$ \\
\hline Log (airports) & $\begin{array}{c}-0.280^{*} \\
(0.11)\end{array}$ & $\begin{array}{l}0.099 \\
(0.07)\end{array}$ & $\begin{array}{c}-5.981+ \\
(3.24)\end{array}$ & $\begin{array}{c}-124.078+ \\
(67.57)\end{array}$ & $\begin{array}{c}0.006+ \\
(0.00)\end{array}$ & $\begin{array}{c}0.113+ \\
(0.06)\end{array}$ \\
\hline Days since first case & $\begin{array}{c}-0.020^{* *} \\
(0.01)\end{array}$ & $\begin{array}{c}-0.005 \\
(0.01)\end{array}$ & $\begin{array}{l}0.085 \\
(0.25)\end{array}$ & $\begin{array}{l}3.621 \\
(4.96)\end{array}$ & $\begin{array}{c}-0.000 \\
(0.00)\end{array}$ & $\begin{array}{c}-0.004 \\
(0.00)\end{array}$ \\
\hline $\mathrm{R}^{2}$ & 0.7897 & 0.8552 & 0.3473 & 0.3142 & 0.1241 & 0.1737 \\
\hline \multirow[t]{3}{*}{ Panel B } & \multicolumn{6}{|c|}{ Two-Stage Least Squares - 2nd Stage } \\
\hline & $(1)$ & $(2)$ & $(3)$ & (4) & $(5)$ & $(6)$ \\
\hline & $\begin{array}{l}\text { Log (deaths p.c.) } \\
\text { weighted by }+65\end{array}$ & Log (deaths) & deaths p.c. & $\begin{array}{c}\text { deaths p.c. } \\
\text { weighted by }+65\end{array}$ & death rate & Log (death rate) \\
\hline Level of Democracy & $\begin{array}{l}0.532^{* * * *} \\
(0.09)\end{array}$ & $\begin{array}{l}0.130^{*} \\
(0.06)\end{array}$ & $\begin{array}{c}10.741^{* * *} \\
(3.26)\end{array}$ & $\begin{array}{c}221.305^{* * *} \\
(66.26)\end{array}$ & $\begin{array}{l}0.003 \\
(0.00)\end{array}$ & $\begin{array}{l}0.057 \\
(0.04)\end{array}$ \\
\hline Log (Confirmed cases) & $\begin{array}{l}0.681^{* * * *} \\
(0.12)\end{array}$ & $\begin{array}{l}0.988^{* * * *} \\
(0.08)\end{array}$ & $\begin{array}{c}10.451^{* *} \\
(3.74)\end{array}$ & $\begin{array}{c}178.980^{*} \\
(74.75)\end{array}$ & $\begin{array}{l}0.000 \\
(0.00)\end{array}$ & $\begin{array}{l}0.091 \\
(0.06)\end{array}$ \\
\hline Log (Real GDP per capita) & $\begin{array}{l}0.036 \\
(0.19)\end{array}$ & $\begin{array}{c}-0.482^{* * *} \\
(0.14)\end{array}$ & $\begin{array}{c}-13.848^{*} \\
(6.55)\end{array}$ & $\begin{array}{c}-267.814^{*} \\
(133.62)\end{array}$ & $\begin{array}{c}-0.014^{* *} \\
(0.01)\end{array}$ & $\begin{array}{c}-0.273^{*} \\
(0.11)\end{array}$ \\
\hline Percentage tropical climate in 2012 & $\begin{array}{c}-0.004 \\
(0.00)\end{array}$ & $\begin{array}{c}-0.001 \\
(0.00)\end{array}$ & $\begin{array}{c}-0.146 \\
(0.09)\end{array}$ & $\begin{array}{c}-3.173+ \\
(1.87)\end{array}$ & $\begin{array}{c}-0.000+ \\
(0.00)\end{array}$ & $\begin{array}{c}-0.002 \\
(0.00)\end{array}$ \\
\hline Population density & $\begin{array}{c}-0.000 \\
(0.00)\end{array}$ & $\begin{array}{c}-0.000 \\
(0.00)\end{array}$ & $\begin{array}{l}0.003 \\
(0.00)\end{array}$ & $\begin{array}{l}0.081 \\
(0.08)\end{array}$ & $\begin{array}{l}0.000 \\
(0.00)\end{array}$ & $\begin{array}{l}0.000 \\
(0.00)\end{array}$ \\
\hline Trade (\% of GDP) & $\begin{array}{l}0.002 \\
(0.00)\end{array}$ & $\begin{array}{l}0.001 \\
(0.00)\end{array}$ & $\begin{array}{l}0.031 \\
(0.09)\end{array}$ & $\begin{array}{c}-0.359 \\
(1.89)\end{array}$ & $\begin{array}{l}0.000 \\
(0.00)\end{array}$ & $\begin{array}{l}0.001 \\
(0.00)\end{array}$ \\
\hline SARS & $\begin{array}{l}0.794 \\
(0.75)\end{array}$ & $\begin{array}{l}0.226 \\
(0.53)\end{array}$ & $\begin{array}{c}-27.289 \\
(19.22)\end{array}$ & $\begin{array}{c}-525.905 \\
(399.37)\end{array}$ & $\begin{array}{c}-0.019 \\
(0.02)\end{array}$ & $\begin{array}{c}-0.249 \\
(0.32)\end{array}$ \\
\hline Log (airports) & $\begin{array}{c}-0.366^{* * *} \\
(0.11)\end{array}$ & $\begin{array}{l}0.083 \\
(0.07)\end{array}$ & $\begin{array}{c}-8.638^{*} \\
(3.90)\end{array}$ & $\begin{array}{c}-177.486^{*} \\
(81.43)\end{array}$ & $\begin{array}{c}0.006+ \\
(0.00)\end{array}$ & $\begin{array}{c}0.110+ \\
(0.06)\end{array}$ \\
\hline Days since first case & $\begin{array}{c}-0.012 \\
(0.01)\end{array}$ & $\begin{array}{c}-0.004 \\
(0.01)\end{array}$ & $\begin{array}{l}0.339 \\
(0.33)\end{array}$ & $\begin{array}{l}8.725 \\
(6.82)\end{array}$ & $\begin{array}{c}-0.000 \\
(0.00)\end{array}$ & $\begin{array}{c}-0.004 \\
(0.00)\end{array}$ \\
\hline First-stage C-D F-stat & 46.688 & 40.311 & 46.688 & 46.688 & 40.311 & 40.311 \\
\hline First-stage K-P F-stat & 41.155 & 36.307 & 41.155 & 41.155 & 36.307 & 36.307 \\
\hline $\mathrm{N}$ & 104 & 106 & 104 & 104 & 106 & 106 \\
\hline
\end{tabular}


Table A.8: Cross-section Two-Stage Tobit regressions - logged COVID-19 Deaths per capita

\begin{tabular}{|c|c|c|c|c|}
\hline & $(1)$ & $(2)$ & $(3)$ & (4) \\
\hline \multicolumn{5}{|l|}{ Dependent Variable: logged COVID-19 Deaths per capita } \\
\hline Level of Democracy (Freedom House/Imputed Polity) & $\begin{array}{c}0.29 * * * \\
(0.06)\end{array}$ & & & \\
\hline Level of Democracy (binary indicator) & & $\begin{array}{c}2.38^{* * * *} \\
(0.60)\end{array}$ & & \\
\hline Political Corruption Index (V-DEM) & & & $\begin{array}{c}-5.75^{* * *} \\
(1.36)\end{array}$ & \\
\hline Performance of Democratic Institutions & & & & $\begin{array}{c}0.05 \\
(0.09)\end{array}$ \\
\hline Log (Confirmed cases) & $\begin{array}{c}0.51^{* * *} \\
(0.09)\end{array}$ & $\begin{array}{c}0.54^{* * *} \\
(0.09)\end{array}$ & $\begin{array}{c}0.57^{* * *} \\
(0.10)\end{array}$ & $\begin{array}{c}0.39^{* * *} \\
(0.08)\end{array}$ \\
\hline Log (Real GDP per capita) & $\begin{array}{l}-0.02 \\
(0.13)\end{array}$ & $\begin{array}{c}0.11 \\
(0.16)\end{array}$ & $\begin{array}{c}-0.62^{* *} \\
(0.24)\end{array}$ & $\begin{array}{c}0.12 \\
(0.09)\end{array}$ \\
\hline Percentage tropical climate in 2012 & $\begin{array}{l}-0.00 \\
(0.00)\end{array}$ & $\begin{array}{l}-0.00 \\
(0.00)\end{array}$ & $\begin{array}{c}0.01 \\
(0.00)\end{array}$ & $\begin{array}{c}0.00 \\
(0.00)\end{array}$ \\
\hline Polpulation density & $\begin{array}{l}-0.00 \\
(0.00)\end{array}$ & $\begin{array}{l}-0.00 \\
(0.00)\end{array}$ & $\begin{array}{l}-0.00 \\
(0.00)\end{array}$ & $\begin{array}{l}-0.00 \\
(0.00)\end{array}$ \\
\hline Trade (\% of GDP) & $\begin{array}{c}0.00 \\
(0.00)\end{array}$ & $\begin{array}{c}0.00 \\
(0.00)\end{array}$ & $\begin{array}{c}0.00 \\
(0.00)\end{array}$ & $\begin{array}{c}0.00 \\
(0.00)\end{array}$ \\
\hline SARS & $\begin{array}{c}0.07 \\
(0.40)\end{array}$ & $\begin{array}{c}0.37 \\
(0.45)\end{array}$ & $\begin{array}{c}-0.85+ \\
(0.51)\end{array}$ & $\begin{array}{c}0.13 \\
(0.41)\end{array}$ \\
\hline Log (airports) & $\begin{array}{c}-0.24^{*-*} \\
(0.07)\end{array}$ & $\begin{array}{c}-0.28^{* *} \\
(0.09)\end{array}$ & $\begin{array}{l}-0.09 \\
(0.11)\end{array}$ & $\begin{array}{l}-0.09 \\
(0.07)\end{array}$ \\
\hline Days since first case & $\begin{array}{c}-0.01+ \\
(0.01)\end{array}$ & $\begin{array}{c}-0.01+ \\
(0.01)\end{array}$ & $\begin{array}{c}-0.03^{* * *} \\
(0.01)\end{array}$ & $\begin{array}{c}-0.02^{* *} \\
(0.01)\end{array}$ \\
\hline $\mathrm{N}$ & 104 & 104 & 104 & 78 \\
\hline
\end{tabular}


Failure: Deaths $!=0$

Analysis time: Days since first case

\begin{tabular}{lccccc}
\hline Category & Total & Mean & Min & Median & Max \\
\hline $\begin{array}{l}\text { No. of observations } \\
\text { No. of countries }\end{array}$ & 4805 & & & & \\
& 114 & & & & \\
(First) entry time & & 0 & 0 & 0 & 0 \\
(Final) exit time & & 25.78876 & 1 & 22 & 99 \\
Observations with gap & 0 & & & & \\
Time on gap if gap & 0 & & & & \\
Time at risk & 123915 & 25.78876 & 1 & 22 & 99 \\
Failures & 2494 & .5190427 & 0 & 1 & 1 \\
\hline
\end{tabular}

Table A.9: Description of the survival data set. On the top left of our table, we display the two characteristics necessary to create our dependent variable: Deaths $!=0$ and Days since the first COVID-19 case. We have 4,805 observations formed by 114 countries. They all start in the data set at time $t_{1}$ (or day zero), and exit at maximum time $t_{k}$ (or 99 days). The mean time to experience the first death case is 25.79 days, and the median time is 22 days. 
Table A.10: Panel OLS regressions - controlling for state capacity and day and region fixed-effects

\begin{tabular}{|c|c|c|c|c|}
\hline & (1) & (2) & (3) & (4) \\
\hline \multicolumn{5}{|l|}{ Dependent Variable: logged COVID-19 Deaths per capita } \\
\hline Level of Democracy (Freedom House/Imputed Polity) & $\begin{array}{c}0.03^{* * *} \\
(0.00)\end{array}$ & $\begin{array}{c}0.04^{* * * *} \\
(0.00)\end{array}$ & $\begin{array}{c}0.04^{* * *} \\
(0.00)\end{array}$ & $\begin{array}{c}0.03^{* * * *} \\
(0.00)\end{array}$ \\
\hline Log (Confirmed cases) & $\begin{array}{c}0.24^{* * *} \\
(0.01)\end{array}$ & $\begin{array}{c}0.24^{* * *} \\
(0.01)\end{array}$ & $\begin{array}{c}0.23^{* * *} \\
(0.01)\end{array}$ & $\begin{array}{c}0.24^{* * *} \\
(0.01)\end{array}$ \\
\hline Log (Real GDP per capita) & $\begin{array}{c}-0.08^{* * * *} \\
(0.01)\end{array}$ & $\begin{array}{c}0.03 \\
(0.02)\end{array}$ & $\begin{array}{l}-0.02 \\
(0.01)\end{array}$ & $\begin{array}{c}-0.07^{* * * *} \\
(0.01)\end{array}$ \\
\hline Percentage tropical climate in 2012 & $\begin{array}{c}0.00^{* * *} \\
(0.00)\end{array}$ & $\begin{array}{c}0.00^{* *} \\
(0.00)\end{array}$ & $\begin{array}{c}0.00 \\
(0.00)\end{array}$ & $\begin{array}{c}0.00^{* * * *} \\
(0.00)\end{array}$ \\
\hline Population density (people per sq. $\mathrm{km}$ of land area) & $\begin{array}{c}0.00 \\
(0.00)\end{array}$ & $\begin{array}{l}0.00^{* *} \\
(0.00)\end{array}$ & $\begin{array}{c}0.00^{* * * *} \\
(0.00)\end{array}$ & $\begin{array}{c}0.00 \\
(0.00)\end{array}$ \\
\hline Trade (\% of GDP) & $\begin{array}{c}0.00^{* * * *} \\
(0.00)\end{array}$ & $\begin{array}{c}0.00^{* * * *} \\
(0.00)\end{array}$ & $\begin{array}{c}0.00^{* * *} \\
(0.00)\end{array}$ & $\begin{array}{c}0.00^{* * * *} \\
(0.00)\end{array}$ \\
\hline SARS & $\begin{array}{c}-0.36^{* * *} \\
(0.03)\end{array}$ & $\begin{array}{c}-0.33^{* * *} \\
(0.03)\end{array}$ & $\begin{array}{c}-0.35^{* * * *} \\
(0.03)\end{array}$ & $\begin{array}{c}-0.36^{* * *} \\
(0.03)\end{array}$ \\
\hline Log (Airports) & $\begin{array}{c}-0.05^{* * * *} \\
(0.01)\end{array}$ & $\begin{array}{c}-0.05^{* * * *} \\
(0.01)\end{array}$ & $\begin{array}{c}-0.05^{* * * *} \\
(0.01)\end{array}$ & $\begin{array}{c}-0.06^{* * * *} \\
(0.01)\end{array}$ \\
\hline Government Effectiveness, Estimate & & $\begin{array}{c}-0.17^{* * * *} \\
(0.02)\end{array}$ & & \\
\hline ICRG Indicator of Quality of Government & & & $\begin{array}{c}-0.78^{* * * *} \\
(0.09)\end{array}$ & \\
\hline State Fragility Index & & & & $\begin{array}{c}0.00 \\
(0.00)\end{array}$ \\
\hline $\mathrm{R}^{2}$ & 0.61 & 0.62 & 0.62 & 0.61 \\
\hline Countries & 104 & 104 & 97 & 101 \\
\hline $\mathrm{N}$ & 6401 & 6401 & 6255 & 6252 \\
\hline
\end{tabular}

All specifications include day and region fixed-effects (not shown) and robust standard errors (in parenthesis). $+p<$ $.1, * p<.05, * * p<.01, * * * p<.001$. 
Table A.11: Panel OLS regressions — state capacity interactions with day and region fixed-effects

\begin{tabular}{|c|c|c|c|}
\hline & (1) & (2) & (3) \\
\hline \multicolumn{4}{|l|}{ Dependent Variable: logged COVID-19 Deaths per capita } \\
\hline Log (Confirmed cases) & $\begin{array}{c}0.24^{* * *} \\
(0.01)\end{array}$ & $\begin{array}{c}0.23^{* * * *} \\
(0.01)\end{array}$ & $\begin{array}{c}0.24^{* * * *} \\
(0.01)\end{array}$ \\
\hline Log (Real GDP per capita) & $\begin{array}{l}0.04^{*} \\
(0.02)\end{array}$ & $\begin{array}{l}-0.02 \\
(0.01)\end{array}$ & $\begin{array}{c}-0.06^{* * *} \\
(0.01)\end{array}$ \\
\hline Percentage tropical climate in 2012 & $\begin{array}{l}0.00^{* *} \\
(0.00)\end{array}$ & $\begin{array}{c}0.00 \\
(0.00)\end{array}$ & $\begin{array}{c}0.00^{* * * *} \\
(0.00)\end{array}$ \\
\hline Population density (people per sq. km of land area) & $\begin{array}{l}0.00^{* *} \\
(0.00)\end{array}$ & $\begin{array}{c}0.00^{* * * *} \\
(0.00)\end{array}$ & $\begin{array}{c}0.00 \\
(0.00)\end{array}$ \\
\hline Trade (\% of GDP) & $\begin{array}{c}0.00^{* * * *} \\
(0.00)\end{array}$ & $\begin{array}{c}0.00^{* * * *} \\
(0.00)\end{array}$ & $\begin{array}{c}0.00^{* * * *} \\
(0.00)\end{array}$ \\
\hline SARS & $\begin{array}{c}-0.32^{* * * *} \\
(0.03)\end{array}$ & $\begin{array}{c}-0.35^{* * * *} \\
(0.03)\end{array}$ & $\begin{array}{c}-0.33^{* * * *} \\
(0.03)\end{array}$ \\
\hline Log (Airports) & $\begin{array}{c}-0.05^{* * * *} \\
(0.01)\end{array}$ & $\begin{array}{c}-0.05^{* * * *} \\
(0.01)\end{array}$ & $\begin{array}{c}-0.06^{* * * *} \\
(0.01)\end{array}$ \\
\hline Level of Democracy (Freedom House/Imputed Polity) & $\begin{array}{c}0.04^{* * *} \\
(0.00)\end{array}$ & $\begin{array}{c}0.04^{* * * *} \\
(0.01)\end{array}$ & $\begin{array}{c}0.05^{* * * *} \\
(0.01)\end{array}$ \\
\hline Government Effectiveness, Estimate & $\begin{array}{c}-0.21^{* * * *} \\
(0.03)\end{array}$ & & \\
\hline Level of Democracy (Freedom House/Imputed Polity) $\times$ Government Effectiveness, Estimate & $\begin{array}{c}0.01 \\
(0.00)\end{array}$ & & \\
\hline ICRG Indicator of Quality of Government & & $\begin{array}{c}-0.72^{* * * *} \\
(0.16)\end{array}$ & \\
\hline Level of Democracy (Freedom House/Imputed Polity) $\times$ ICRG Indicator of Quality of Government & & $\begin{array}{l}-0.01 \\
(0.02)\end{array}$ & \\
\hline State Fragility Index & & & $\begin{array}{c}0.02^{* * * *} \\
(0.00)\end{array}$ \\
\hline Level of Democracy (Freedom House/Imputed Polity) $\times$ State Fragility Index & & & $\begin{array}{c}-0.00^{* * * *} \\
(0.00) \\
\end{array}$ \\
\hline $\mathrm{R}^{2}$ & 0.62 & 0.62 & 0.61 \\
\hline Countries & 104 & 97 & 101 \\
\hline $\mathrm{N}$ & 6401 & 6255 & 6252 \\
\hline
\end{tabular}

All specifications include day and region fixed-effects (not shown) and robust standard errors (in parenthesis). $+p<$ $.1, * p<.05, * * p<.01, * * * p<.001$. 


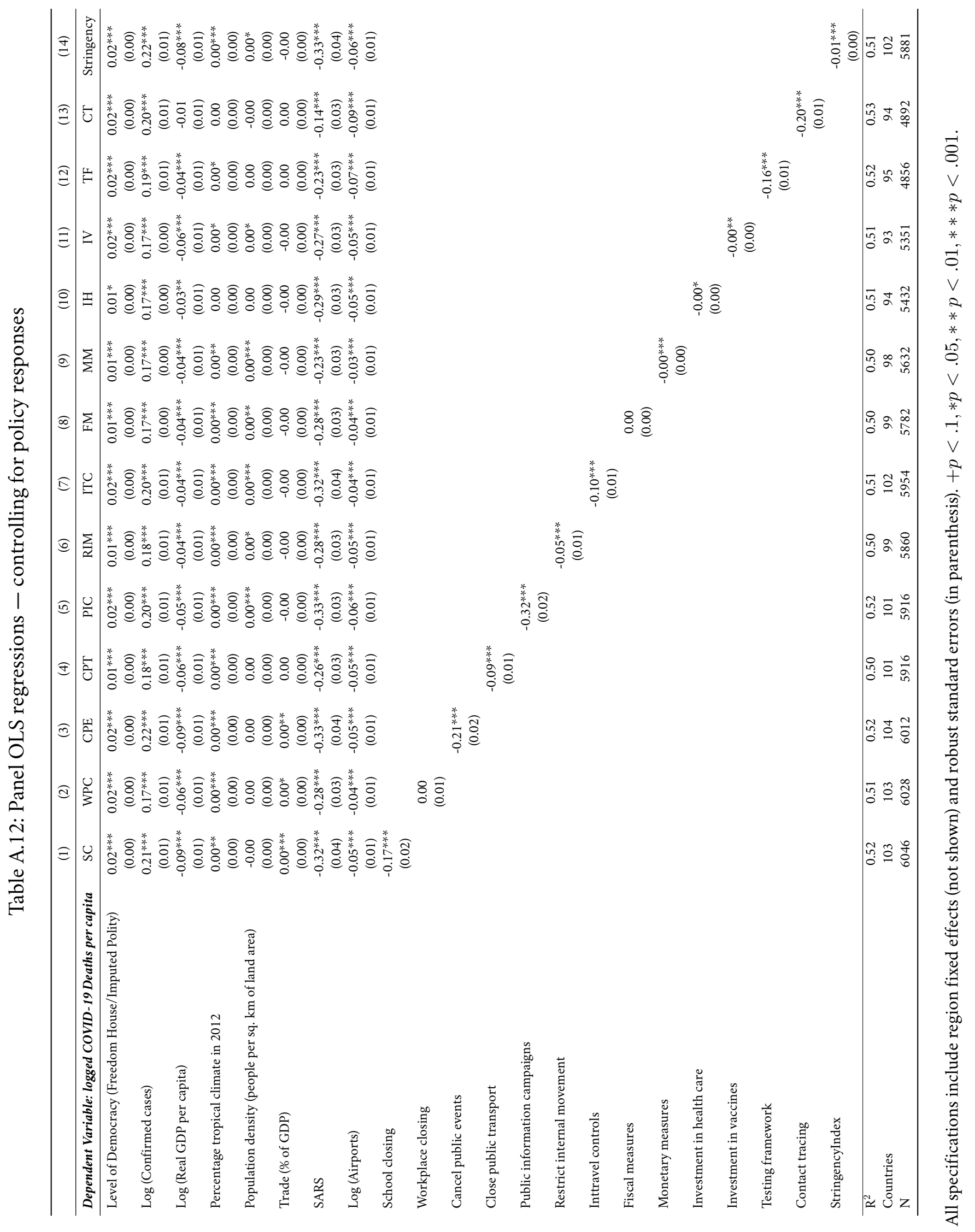




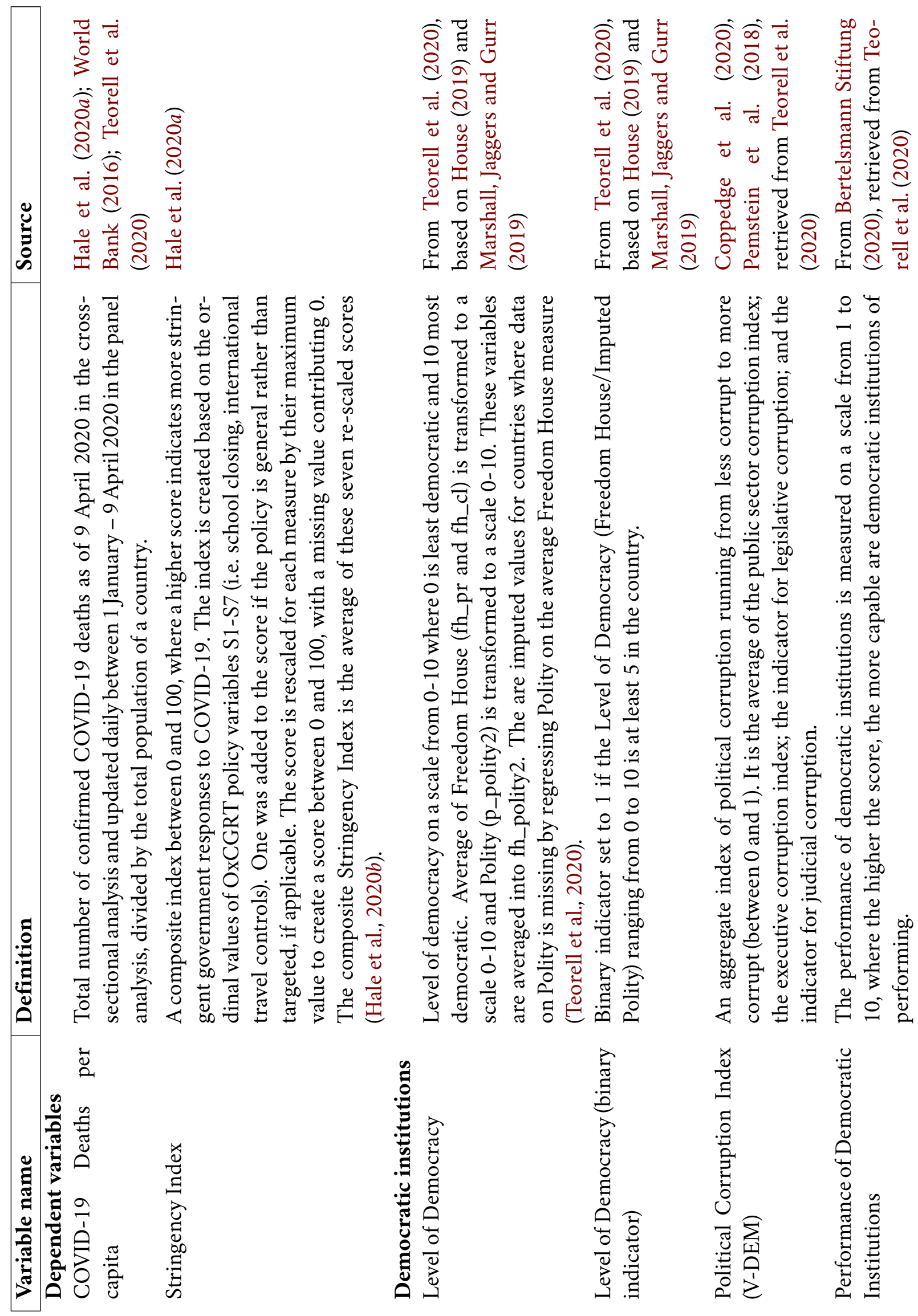




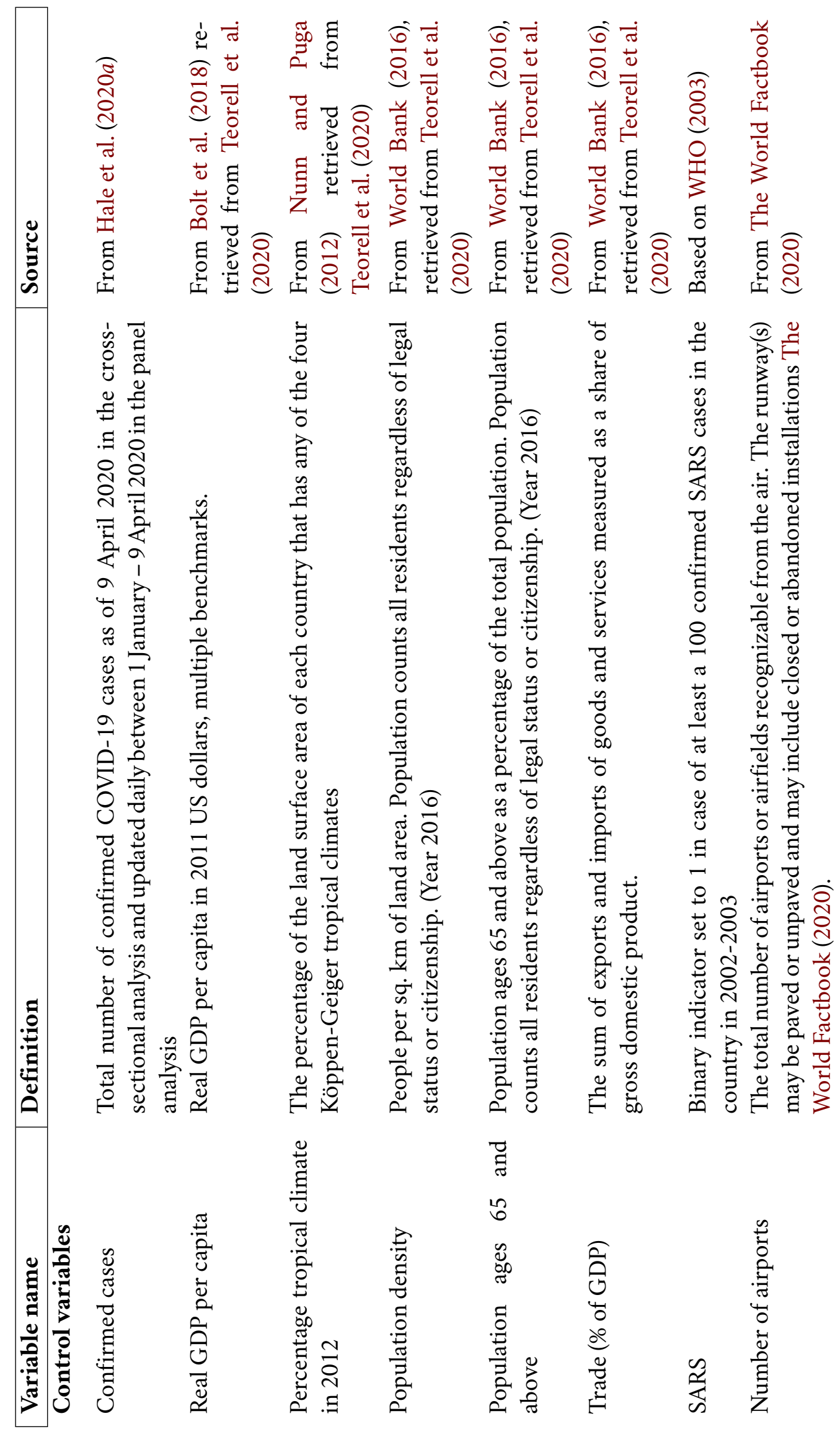




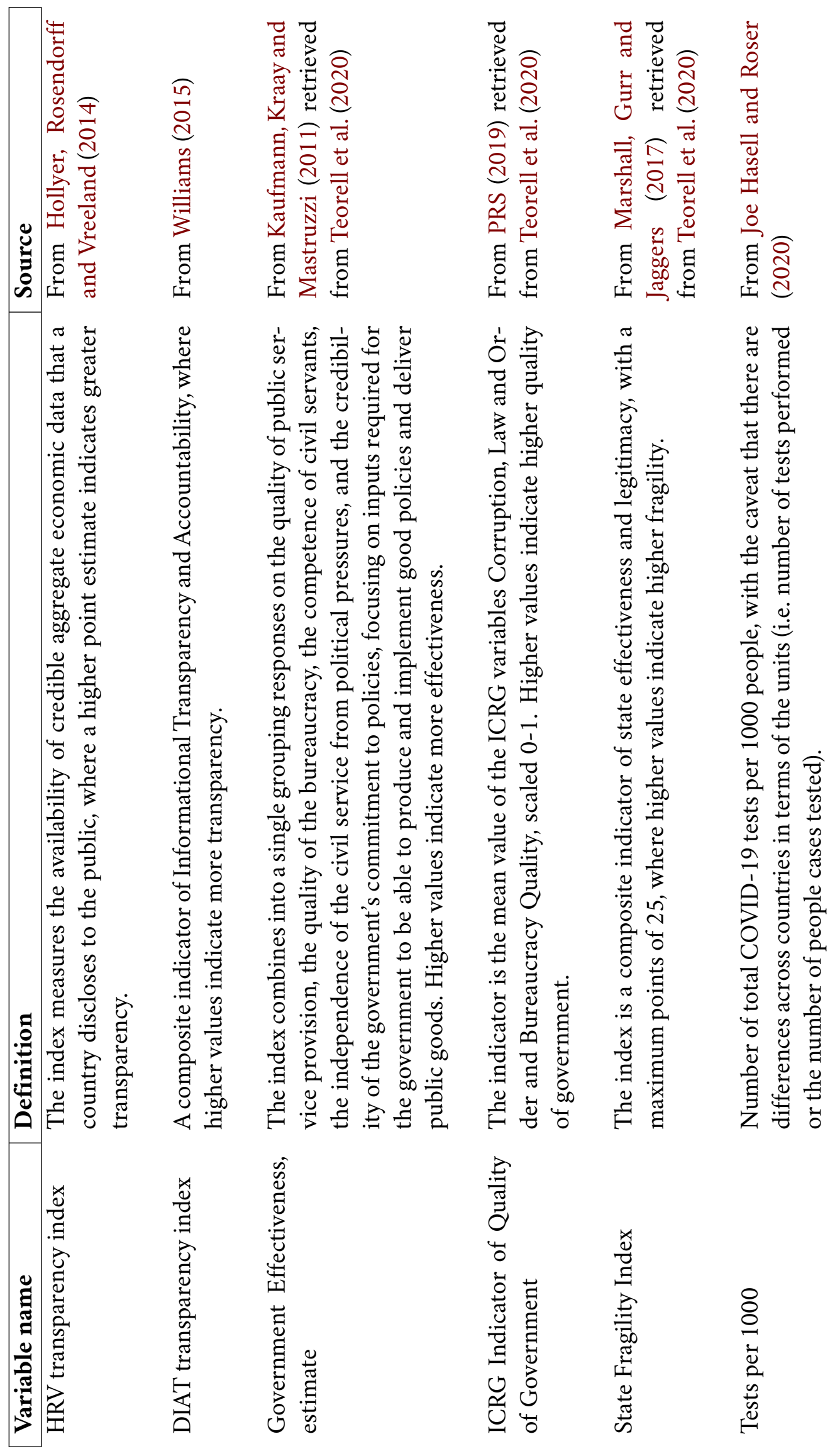




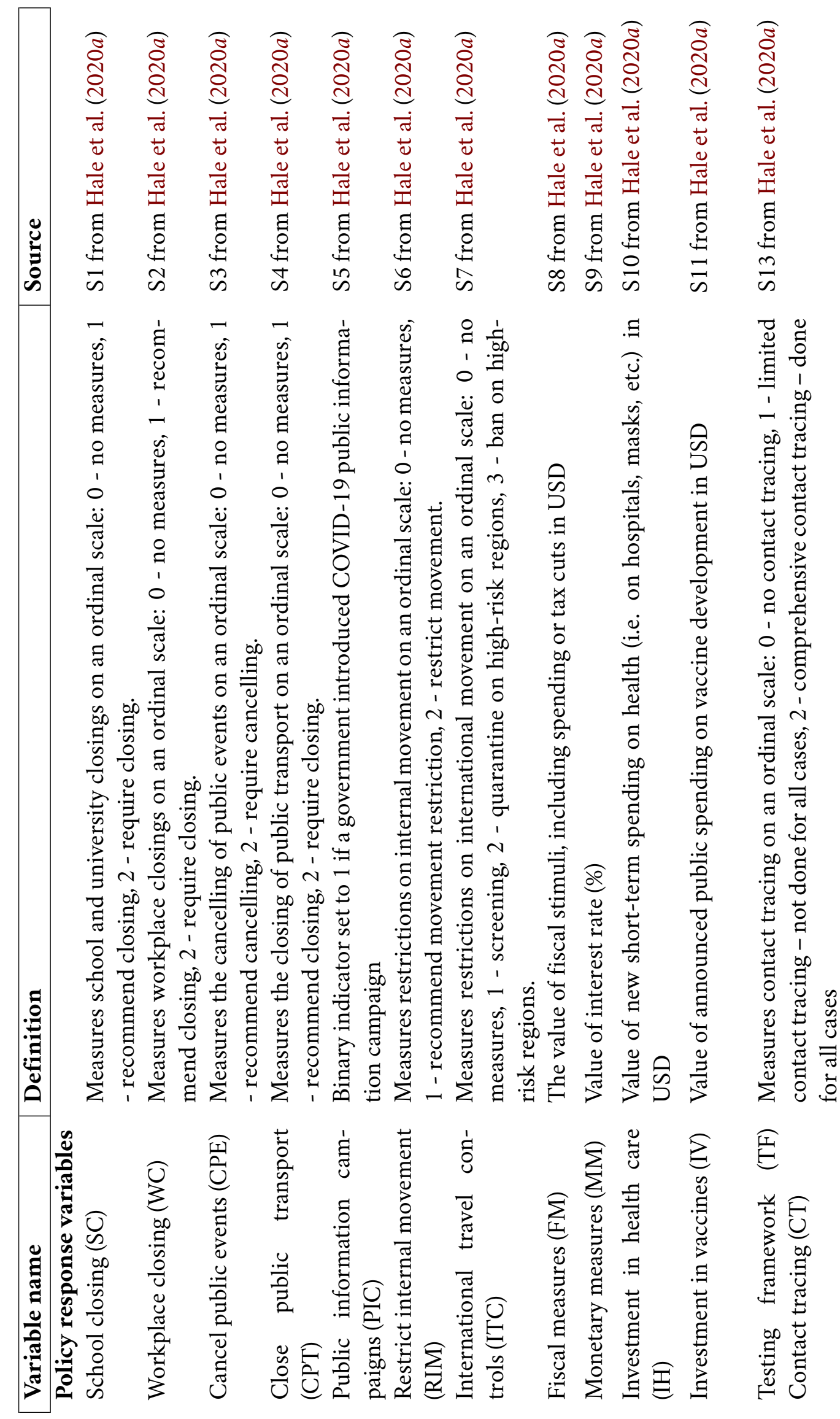

